\title{
Building large trees by combining phylogenetic information: a complete phylogeny of the extant Carnivora (Mammalia)
}

\author{
OLAF R. P. BININDA-EMONDS ${ }^{1 *}$, JOHN L. GITTLEMAN $^{2} \dagger$ \\ and ANDY PURVIS ${ }^{3}$ \\ ${ }^{1}$ Department of Zoology, University of Oxford, Oxford OX1 3PS, U.K. \\ ${ }^{2}$ Department of Ecology and Evolutionary Biology, University of Tennessee, Knoxville, Tennessee, 37996-1610, U.S.A. \\ ${ }^{3}$ Department of Biology, Imperial College at Silwood Park, Ascot, Berks SL5 7PY,U.K. E-mail: a.purvis@ic.ac.uk
}

(Received 2 June 1998; revised 27 November 1998; accepted 16 December 1998)

\begin{abstract}
One way to build larger, more comprehensive phylogenies is to combine the vast amount of phylogenetic information already available. We review the two main strategies for accomplishing this (combining raw data versus combining trees), but employ a relatively new variant of the latter: supertree construction. The utility of one supertree technique, matrix representation using parsimony analysis (MRP), is demonstrated by deriving a complete phylogeny for all 271 extant species of the Carnivora from 177 literature sources. Beyond providing a 'consensus' estimate of carnivore phylogeny, the tree also indicates taxa for which the relationships remain controversial (e.g. the red panda; within canids, felids, and hyaenids) or have not been studied in any great detail (e.g. herpestids, viverrids, and intrageneric relationships in the procyonids). Times of divergence throughout the tree were also estimated from 74 literature sources based on both fossil and molecular data. We use the phylogeny to show that some lineages within the Mustelinae and Canidae contain significantly more species than expected for their age, illustrating the tree's utility for studies of macroevolution. It will also provide a useful foundation for comparative and conservational studies involving the carnivores.
\end{abstract}

Key words: Carnivora, character congruence, taxonomic congruence, supertree, matrix representation, parsimony, divergence times, fossil dates, molecular clock, macroevolution.

\section{CONTENTS}

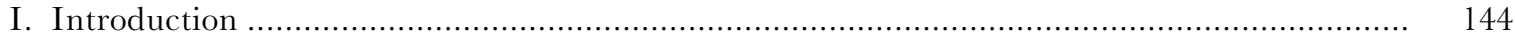

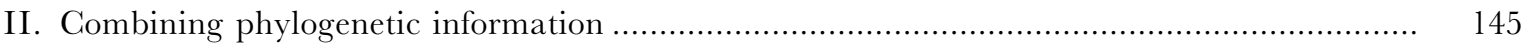

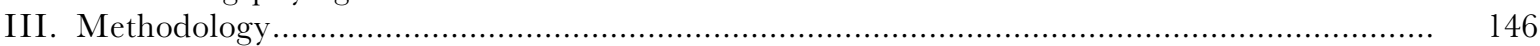

(1) Mechanics and limitations of matrix representation ............................................ 146

(2) Determination of the composite phylogeny........................................................... 147

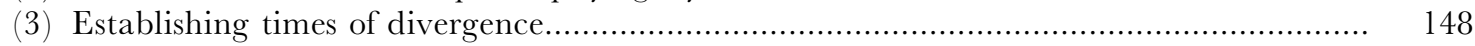

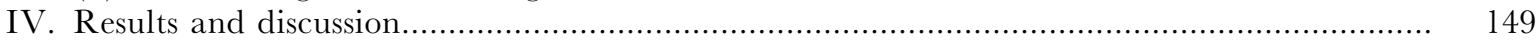

(1) Distribution of taxonomic coverage …................................................................ 149

* Present address: Section of Evolution and Ecology, One Shields Avenue, University of California at Davis, Davis, CA 95616, U.S.A. E-mail: orbininda@ucdavis.edu.

$\dagger$ Present address: Department of Biology, Gilmer Hall, University of Virginia, Charlottesville, VA 22903, U.S.A. E-mail: JLGittleman@virginia.edu. 


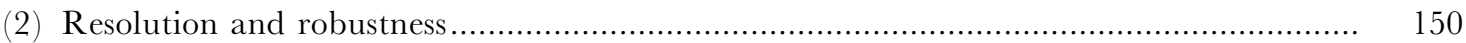

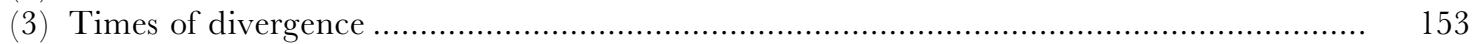

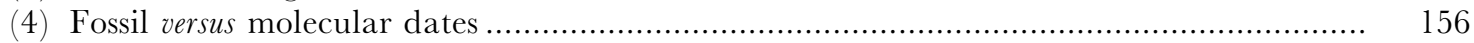

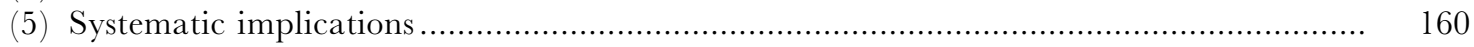

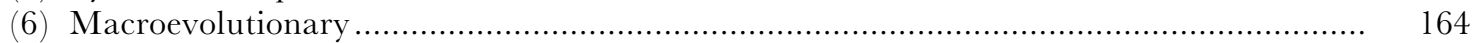

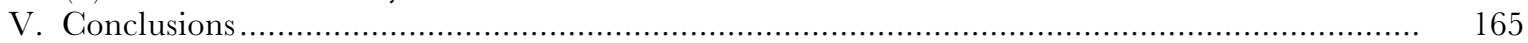

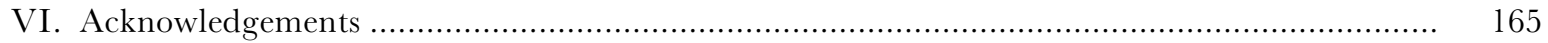

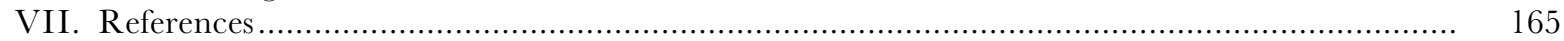

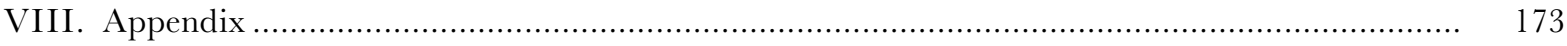

\section{INTRODUCTION}

The benefits of a complete phylogeny for a given taxon (beyond the systematic ones) are clear. Phylogenies underpin comparative biology (Felsenstein, 1985 b; Harvey et al., 1996), and trees that are well-resolved, complete, and include estimates of divergence dates allow more powerful tests of a wider range of hypotheses (Harvey \& Pagel, 1991). In addition to facilitating general studies of adaptation, complete phylogenies are critical for testing macroevolutionary hypotheses (Purvis, 1996; Mooers \& Heard, 1997). For instance, have rates of diversification varied over time or among lineages? Are there any recurring correlates of diversity (e.g. key innovations, environmental or ecological factors, biogeographic events)? Finally, complete phylogenies may have implications for conservation efforts (Humphries, Williams \& Vane-Wright, 1995; Vázquez \& Gittleman, 1998).

Attempts to generate complete phylogenies from primary data face two size-related limitations: (1) obtaining sufficient data that are informative for all sets of relationships spanning the history of the group in question and (2) the inability of current computer algorithms to find optimal trees for more than approximately 20 taxa (Swofford, 1993). The first limitation is perhaps the more serious. Although optimal solutions cannot be guaranteed for analyses with large numbers of taxa, heuristic search algorithms appear to be remarkably powerful (Swofford, 1993), particularly when prefaced by the combination of compartmentalization (Mishler, 1994) whereby large data sets are broken down into more manageable nested subsets, and parsimony jackknifing (Farris et al., 1996), which is a fast procedure for detecting well-supported clades.

Despite the recent explosion in phylogenetic studies, the uneven distribution of research effort across taxa and of the resulting phylogenetic information into many individual studies means that homologous data (e.g. the same gene sequences or morphological characters) for all members of a group often do not exist. Furthermore, when such data exist, they frequently cannot resolve relationships throughout the tree, particularly for groups with long evolutionary histories. One solution is a coordinated effort to fill in the missing information. A simpler and more cost-effective solution might be to combine the vast amount of phylogenetic information that already exists, and this is the strategy we employ herein for the carnivores.

The mammalian order Carnivora is a diverse collection of 271 extant species (following Wozencraft, 1993) found on every continent and occupying habitats ranging from oceans to rainforest and deserts. Carnivores range in body size over four orders of magnitude - more than any other mammalian order - and are also notably diverse in their physiology, social structure, and, despite their ordinal name, their feeding ecology. Furthermore, there are marked differences in the current species richness among high-level taxa (e.g. there are 65 mustelids and only four hyaenids).

Recent comparative studies of adaptation in the Carnivora include the evolution of life histories (e.g. Gittleman, 1994a), colour patterns (e.g. Ortolani \& Caro, 1996), body, brain, and skull size (e.g. Gittleman, 1994b; Gittleman \& Van Valkenburgh, 1997), home-range size (e.g. Garland et al., 1993), energetics and physiology (e.g. Lee, Majluf \& Gordon, 1991; McNab, 1995), and social structure (e.g. Creel \& Macdonald, 1995; Geffen et al., 1996). Yet, despite its utility for studying carnivore evolution, no complete species-level phylogeny has ever been assembled for this diverse and varied order. All the above studies were limited by having only a partial or poorly resolved phylogeny of the carnivores available that included only a number of key taxa (rarely more than 30) spread throughout the order (e.g. Wayne et al., 1989 a; Garland et al., 1993; Wyss \& Flynn, 1993; Vrana et al., 1994; Ledje \& Arnason, 1996).

We initially introduce methods of combining phylogenetic information, focusing particularly on constructing a phylogenetic supertree (Sanderson, 
Purvis \& Henze, 1998) by matrix representation with parsimony analysis (MRP; Baum, 1992; Ragan, 1992). We then illustrate the utility of MRP for building larger, more comprehensive phylogenies by deriving the first complete species-level phylogeny of extant carnivores based on a thorough survey of the systematic literature from the past 25 years. We also date the nodes in the resulting cladogram as fully as possible, following methods in Purvis $(1995 a)$. The carnivore 'supertree' will facilitate tests of comparative hypotheses as we demonstrate with some preliminary macroevolutionary analyses. We stress, however, that our tree is not intended to be the final word in carnivoran phylogeny, but is intended more to provide a working hypothesis, to provoke alternative hypotheses, and to direct more systematic attention to groups that have so far received little or none.

\section{COMBINING PHYLOGENETIC INFORMATION}

As mentioned above, existing information can be reexamined to provide more complete estimates of phylogeny. Historically, two approaches have dominated, both of which were initially devised to assess the degree of congruence between independent data sets. 'Character congruence' (sensu Kluge, 1989) operates by combining and re-analysing the raw (primary) data to derive the most consistent, unified statement regarding relationships among a set of taxa (Swofford, 1991). With 'taxonomic congruence' (sensu Mickevich, 1978), the data sets are analysed individually and the resultant trees are combined using consensus techniques to indicate those clades supported by the most independent lines of evidence (Swofford, 1991). We discuss the advantages and limitations of each approach in turn before introducing a recently developed technique: constructing phylogenetic supertrees (sensu Sanderson et al., 1998) using MRP (Baum, 1992; Ragan, 1992).

Character congruence has been promoted largely on the principle of 'total evidence' (sensu Kluge, 1989): the best phylogenetic hypothesis is the one that uses all the available data and then as much information within those data as possible. Its appeal to many derives from the advantages of combining the raw data. First, signals and subsignals within the data can interact to support one another, yielding relationships that were not indicated by any single source study ('signal enhancement', de Queiroz, Donoghue \& Kim, 1995; also Nixon \& Carpenter,
1996). Second, studies are easily differentially weighted to reflect confidence levels and sample sizes. Finally, using the raw data means that the descriptive and explanatory power of the solution is maximized (Kluge \& Wolf, 1993; Nixon \& Carpenter, 1996). For instance, the solution can be used to infer processes such as character evolution and support for it can be summarized using standard metrics such as goodness-of-fit indices (Swofford, 1991), bootstrapping (Felsenstein, $1985 a$ ), or Bremer support (Källersjö et al., 1992).

Disadvantages of character congruence include the necessity of a single clustering or tree-building technique (typically parsimony), which limits its use to compatible data types only. Another potential problem is whether data pointing to vastly different solutions should be combined. This statistical argument takes its lead from ecology where one routinely tests for data heterogeneity prior to prospective pooling. Many have argued against combining phylogenetic data lacking a single underlying distribution (e.g. Bull et al., 1993; de Queiroz et al., 1995), but some remain unconvinced (e.g. Nixon \& Carpenter, 1996).

Taxonomic congruence instead combines trees and thus is one step removed from the primary data. To many, this is a less desirable approach, such that taxonomic congruence is advocated more as a fallback option when character congruence cannot be applied (e.g. data heterogeneity or incompatibility) (Bull et al., 1993; Rodrigo et al., 1993; de Querioz et al., 1995). This dual strategy has been referred to as either 'prior agreement' (Chippindale \& Wiens, 1994) or the 'conditional combination approach' (Huelsenbeck, Bull \& Cunningham, 1996). Taxonomic congruence has also been criticized because the choice of consensus technique used to combine the source trees is essentially arbitrary (Kluge, 1989).

However, the strategy of combining trees presents certain advantages. Methodologically, consensus techniques find solutions in polynomial time as opposed to the less efficient non-polynomial time of optimization-based tree-building techniques (Graham \& Foulds, 1982). Therefore, taxonomic congruence is less prone to size limitations than is character congruence. Data sets are also combined equally, preventing smaller ones from being 'swamped'. Concerns about swamping have been strongest for combining morphological and molecular data sets as the latter tend to be much larger (Kluge, 1983; Miyamoto, 1985; Barrett, Donoghue \& Sober, 1991). However, swamping may be less of a problem than formerly thought: most molecular 
characters are not phylogenetically informative (i.e. they are invariant or the changes do not cluster taxa) and so the two sources are often more equal in size than they might first appear. Finally, it is easier to visualize conflict between data sets using taxonomic congruence because conflicting regions contain polytomies (although this depends on the consensus technique used to some degree). This becomes important philosophically because many hold the best hypothesis to be the one that has the most independent lines of evidence supporting it (Mickevich, 1978; Farris, 1983; Penny \& Hendy, 1986; Novacek, 1992b).

A new solution for combining phylogenetic information is constructing phylogenetic supertrees. Building supertrees, for which MRP is one method, resembles taxonomic congruence methodologically in that trees are combined rather than raw data. Thus, supertrees can combine heterogeneous or incompatible data. However, because the algorithms do not use (conventional) consensus techniques to do so, a distinguishing feature of supertrees is that the source trees can possess different sets of terminal taxa. [Except for Lanyon's (1993) modified semistrict consensus algorithm, all consensus techniques require source trees to have the same set of taxa.]

Due to its mechanics, MRP also possesses properties reminiscent of character congruence. Briefly, MRP represents the pattern of relationships within a source tree as a series of binary elements ('characters') describing each node in turn. Descendants of a node are scored as ' 1 ', all others (except taxa missing from that source tree which receive '?') as '0' (Baum, 1992; Ragan, 1992). An all-zero hypothetical outgroup is used to polarize the elements. A parsimony algorithm perfectly reconstructs any single tree coded in this manner and is the 'most efficient' means (Baum \& Ragan, 1993, p. 638) of deriving a composite tree from many source trees (Baum, 1992; Ragan, 1992).

Because trees are a graphical representation of the signal within a data set, MRP is essentially a parsimony analysis of the different phylogenetic signals within each data set stripped of any confounding noise (i.e. homoplasy). Thus, it obtains character congruence-like properties such as occasionally indicating clades not found among any of the source trees (analogous to signal enhancement) and is less sensitive to conflict among source trees in that the composite tree is usually well resolved (Barrett et al., 1991; Purvis, 1995 b; Bininda-Emonds \& Bryant, 1998). Furthermore, differential levels of support, both within and among source trees, can be accounted for by weighting (Purvis, 1995 $b$; Ronquist, 1996). Unfortunately, MRP faces size limitations like any parsimony analysis, although MRP analyses tend to be relatively 'clean', allowing more taxa than usual to be analysed using exact search algorithms.

An important distinction between MRP and character congruence techniques is that the matrix elements generated by MRP's coding procedure for each source tree are not independent, forming cliques of elements that support one another. Because of this, support for MRP analyses should not be summarized by techniques like bootstrapping that assume character independence (Purvis, 1995b). Moreover, it means that MRP has a size bias. Bigger, more resolved source trees contribute more elements to the overall matrix and so tend to have greater impact on the composite tree (Ronquist, 1996; Bininda-Emonds \& Bryant, 1998). Attempts to correct for the size bias using differential weighting (Ronquist, 1996) or a modified coding procedure (Purvis, 1995b) have been unsuccessful or shown to be theoretically flawed (Ronquist, 1996; BinindaEmonds \& Bryant, 1998). It is debatable whether the bias is a shortcoming, but it does not appear to be correctable and, at the very least, will cause MRP to 'combine trees' in a way we might not be accustomed to. However, the bias is most apparent when very limited numbers of source trees are combined; with increasing numbers (as herein), differences arising because of the bias appear to be small (for a more complete discussion of this issue see Bininda-Emonds \& Bryant, 1998).

The full potential of MRP to combine phylogenetic information has yet to be fully explored; however, it has already been used to produce a composite tree for all extant primate species (Purvis, $1995 a)$ and ones for bats, insectivores, and marsupials are currently under construction.

\section{METHODOLOGY}

\section{(1) Mechanics and limitations of matrix representation}

In addition to its potential shortcomings mentioned above, MRP as applied here also has some historically-based limitations. To some degree, the method amounts to a majority rule summary of past and present systematic opinion, and so will be heavily biased against new, non-traditional hypotheses, even if they are now widely accepted. A case in point is the recent contention by Wyss (1987) of a 
walrus-phocid pairing to the exclusion of the otariids. Although currently accepted by many pinniped systematists (e.g. Flynn, 1988; Berta, 1991; Cozzuol, 1992; Wyss \& Flynn, 1993; Berta \& Wyss, 1994; Vrana et al., 1994), this hypothesis has not yet accumulated sufficient support to outweigh the more traditional view of a walrus-otariid pairing. Results from molecular studies would be expected to suffer the most from this bias due to the relatively recent origin of the field.

Additionally, our analyses do not provide a strong test of the monophyly of some taxa because many of our sources tacitly assume the monophyly of taxa above the species level. We have minimized this problem whenever possible by identifying the species being referred to; however, this was often not possible with older references, particularly those that listed groups in a taxonomic fashion (thereby implicitly including all species).

\section{(2) Determination of the composite phylogeny}

Potential source trees were identified from on-line searches of the Science Citation Index (1981-95; via Bath Information and Data Services), Biological Abstracts (1990-5), and Zoological Record (197895) for any of the key words cladistic*, clado*, classif*, phylogen*, systematic*, or taxonom* in combination with any major carnivoran taxon name (scientific or common). Additional sources were obtained from references within previously found articles. We restricted the search to between the years 1970 and 1995 inclusive. Exceptions were made only for 'landmark' articles (e.g. Gregory \& Hellman, 1939; Leone \& Wiens, 1956), 'in press' articles of which we were aware of by the end of 1995, and articles for groups (notably the herpestids and viverrids) that otherwise yielded too few source trees. Species assignments followed Wozencraft (1993).

Our phylogeny explicitly details relationships among extant carnivorans, for which we have followed a recent and widely accepted species list (Wozencraft, 1993). To our knowledge, this list excludes only two putative carnivore species (besides the domestic cat and dog): the Iriomote cat (Felis iriomotensis) and a newly described viverrid (Viverra tainguensis; Sokolov, Rozhnov \& Anh, 1997). However, the Iriomote cat was held to be an island subspecies of the leopard cat (Felis bengalensis) by Wozencraft (1993) and the taxonomic status of $V$. tainguensis requires verification. Additionally, recog- nizing that fossil information can overturn phylogenetic hypotheses based on extant forms alone Gauthier, Kluge \& Rowe, 1988; Donoghue et al., 1989; Novacek, 1992a), we included source trees with fossil and extant species whenever possible.

Source trees were obtained from a total of 177 publications (see Appendix and Table 1 for a breakdown according to family). Only that information which the author(s) indicated to have phylogenetic relevance was used. Where a researcher or group has published a series of papers using virtually the same methodology and data source, only the most recent and complete study was used. However, when different researchers analysed the same data source, we used each tree because differences in the analyses (e.g. assumptions, use of different segments of the same gene) might change the results between the studies. Finally, when a source contained multiple analyses of a given data set, we combined the results of these analyses into a single source tree using MRP.

Unlike Purvis $(1995 a)$, we drew no distinction between source trees based on the type of analysis used to obtain them. Hence, all elements from all source trees received equal weight in the final analysis. Because any choice of weights, including equal weighting, is inevitably subjective (Barrett et al., 1991), we also examine the effects of a differential weighting scheme (see Purvis, 1995a).

The size of the problem precluded an efficient single analysis of all species, so composite estimates were made for the following taxa: Canidae, Felidae, Herpestidae, Hyaenidae, Mustelidae (and Lutrinae and Mephitinae therein), Otariidae, Phocidae, Procyonidae, Ursidae (including the giant panda, Ailuropoda melanoleuca), and Viverridae, and one linking these taxa plus the monotypic walrus (Odobenus rosmarus) and red panda (Ailurus fulgens) together ('higher groups'). The nested estimates were combined into a single tree in a process akin to compartmentalization. Most of these groups are widely, if not universally, accepted as monophyletic. The only substantive objections that might be raised lie with grouping Ailuropoda melanoleuca with the ursids, and the assumed monophyly of procyonids, mustelids and viverrids. Despite the historical controversy surrounding the relationships of Ailuropoda melanoleuca, the clear majority now hold it to be a primitive ursid (O'Brien et al., 1985; see Mayr, 1986 for a summary). Among recent studies, only Peters (1982) and Tagle et al. (1986; but see Czelusniak et al., 1991) dissent from this view. Support for a monophyletic Procyonidae comes from Seal, Phillips 
\& Erickson (1970), Baskin (1982, 1989), Wozencraft (1989), and Decker \& Wozencraft (1991). While growing evidence exists that the mephitines are only distantly related to the remaining mustelids (Arnason \& Widegren, 1986; Wayne et al., $1989 a$; Arnason \& Ledje, 1993; Vrana et al., 1994; Ledje \& Arnason, 1996), this claim still requires further substantiation. There is also speculation that the African palm civet (Nandinia binotata) may be a primitive feloid, and not a viverrid, based on the primitive morphology of its auditory bulla (Hunt, 1974; Wiig, 1985; Flynn, Neff \& Tedford, 1988; Hunt \& Tedford, 1993; Flynn, 1996), but we could not adequately test this hypothesis because the topological disparity of the two hypotheses was difficult to accommodate under the constraints of the nested analysis. Therefore, we assumed Nandinia binotata to be a viverrid.

Matrices were constructed using the data editor of MacClade 3.05 (Maddison \& Maddison, 1992). A hypothetical all-zero outgroup was added to each to polarize the elements. All matrices were analysed with PAUP 3.1.1 (Swofford, 1993). The exact branch-and-bound algorithm was used for matrices with fewer than 20 taxa. For larger matrices, we used the approximate heuristic algorithm with a random addition sequence (25 repetitions), TBR branch swapping on minimal trees only (steepest descent on), collapsed zero length branches, and unlimited MAXTREES. Equally most parsimonious solutions were summarized using strict consensus.

Only one search could not be completed due to memory limitations. Initial results for the herpestids were highly unresolved (see Fig. $11 \mathrm{~A}$ ), with at least 30000 most parsimonious solutions, because many herpestid species have scarcely been investigated systematically. Because the phylogenetic position of many species is unknown beyond a certain level (e.g. subfamilial or generic assessment), MRP indicates all placements within that clade to be equally parsimonious, collapsing the clade to a bush under strict consensus. To improve resolution within this family, we applied safe taxonomic reduction (Wilkinson, 1995) to identify poorly known taxa whose (few) matrix elements were identical with those of one or more of the more completely known species and provided no novel clustering information. Twelve species were identified in this manner and removed from the analysis. However, contra Wilkinson (1995), these species were reinserted into the tree at the most basal position indicated for them in the literature (dashed branches in Fig. $11 \mathrm{~B}$ ). For example, both Dologale dybowskii and Rhynchogale melleri are known to be herpestines, but no study has placed them any more precisely, so both taxa were added to the basal node of this subfamily. Such placements do not strictly reflect phylogeny (although weak membership statements can be made from them), but rather identify poorly studied taxa, much like Adams consensus (Adams, 1972) identifies 'rogue' taxa among many competing source trees. Although the same lack of information applied to the intrageneric relationships of the procyonids (see Fig. 5 ), safe taxonomic reduction could not improve the resolution there.

We use Bremer support (Bremer, 1988; Källersjö et al., 1992) to estimate the robustness of each node in the composite tree. Bremer support indicates how much less parsimonious the tree would have to be before the clade in question disappears. Bremer support depends on how many characters or elements there are (Novacek, 1991) and how well they agree, so values may be low because of small numbers of source trees or conflict among them (see 'Results and Discussion').

\section{(3) Establishing times of divergence}

Following Purvis (1995a), a combination of absolute (fossil and point molecular estimates) and relative (molecular) dates from the literature were used to date the composite tree (see Appendix). Both kinds of data present inherent difficulties.

No clear guidelines have emerged for estimating times of divergence from the fossil record. We followed Wayne, Van Valkenburgh \& O'Brien (1991) in using the time of first occurrence of either descendant lineage, unless there was good phylogenetic or biogeographic evidence to the contrary. One problem with fossil information is the greater instability of fossil systematics (e.g. see McKenna \& Bell, 1997). This reflects (1) changes in phylogenetic opinion caused by the discovery of new species or of additional material for poorly known species, and (2) that, historically, fossil species were frequently grouped taxonomically rather than phylogenetically. (Similar problems affect analyses of extant forms, but are generally less severe and fossil systematics is becoming increasingly based on more robust, cladistic methodology.) Taxonomic groupings tend to be unstable at many levels (e.g. tribe, subfamily), something also arising from shifts in phylogenetic opinion. Thus, the context of a taxon might have changed since a fossil species was assigned to it. For example, Viverridae long included mongooses and kin as the subfamily Herpestinae 
(despite the lack of any derived features uniting them; see Wozencraft, 1989). However, since Wozencraft (1989), the elevation of mongooses (as Herpestidae) to equivalent status as viverrids has been increasingly accepted. Thus, when using fossil information that predates this taxonomic change, one must ensure that the fossil 'viverrid' is what we would recognize as a viverrid today.

Furthermore, not all fossil information is usable in the current context. The absence of fossil species in our phylogeny means the divergence estimated by many fossils will not be present, particularly those that predate the most recent common ancestry of the extant taxa. For example, Hesperocyon is widely regarded as the oldest known canid, but since it is not a member of the clade including extant forms (Savage \& Russell, 1983; Wang, 1994), its time of first occurrence cannot be used to date their radiation. Information from Hesperocyon would, however, be appropriate for dating the divergence of all canids from the remaining caniforms.

Altogether, these problems necessitate care to be exercised when using fossil dates. Our general strategy was to use information from relatively well known and stable fossil species only and then to use it to establish divergence times for nodes equivalent to the more robust taxonomic levels (generally families and genera). This strategy provided dates for 129 nodes.

The use of molecular data to derive times of divergence is hampered by different lineages evolving at different rates (Gillespie, 1991; Wayne et al., 1991; Flynn, 1996) and evidence of a decrease in the rate of change with increasing divergence times (Wayne et al., 1991; Gittleman et al., 1996). As such, calibrating molecular information to a few widely spaced nodes of known age will likely lead to correlated errors (and typically underestimates; Wayne et al., 1991) throughout the tree. As in Purvis $(1995 a)$, the concept of a local molecular clock (Bailey et al., 1991) was employed to minimize potential errors. Briefly, this method estimates the date of a node relative to some (not necessarily immediately) ancestral node based on relative branch lengths (see Purvis, $1995 a$ for more detail and a worked example). Whenever possible, the branch lengths we used for this were derived from the original pairwise matrices in the source paper.

A total of 74 studies yielded 545 point estimates (293 fossil, 236 molecular and 16 from a study assimilating both types) for 150 nodes throughout the tree. To minimize the effect of outliers, the divergence time for a node was calculated as the median of available estimates. Whatever their source, estimates of divergence time are likely to be underestimates. Fossil dates will consistently be so because the first appearance in the fossil record need not correspond with the origin of a taxon (Marshall, 1990; Flynn, 1996). This bias will, in turn, affect the relative molecular estimates, as we calibrated such estimates against fossil dates. The negative correlation between divergence time and the rate of molecular change further compounds this problem for molecular estimates, particularly when calibrations are based on only a few nodes. We therefore incorporated fossil dates throughout the tree (unlike Purvis, 1995a).

Finally, dates for those nodes that did not possess an estimate in the literature were interpolated using a pure birth model, under which a clade's age is proportional to the logarithm of the number of species it contains (see Purvis, 1995a, p. 416). Estimates were calibrated relative to dated ancestral and, unlike Purvis (1995a), from dated descendent nodes whenever possible. The use of more than one calibration point should reduce errors associated with erroneous dating of calibration points. Our interpolations are intended more to accommodate those comparative methods requiring a complete set of branch lengths than as precise estimates of divergence times. Factors such as extinction may differentially reduce the representation of some of the older lineages and other related biases also exist. Fortunately, comparative methods are reasonably robust to errors in branch length information (Purvis, Gittleman \& Luh, 1994) and the majority of nodes (150 of 211) had divergence times derived from literature estimates.

\section{RESULTS AND DISGUSSION}

\section{(1) Distribution of taxonomic coverage}

Prior systematic effort has not been distributed evenly throughout the carnivores (Table 1). The groups for which there are most source trees include canids, felids, mustelids, phocids, ursids, and the interfamilial relationships of the carnivores. This uneven distribution of effort has many causes. Geographic distribution (largely Africa and southern Asia) and cryptic habits both count against herpestids and viverrids, whereas some families have been targeted by particular research groups (e.g. U. Arnason \& colleagues for phocids, S. J. O'Brien \& colleagues for felids, R. K. Wayne \& colleagues for canids), often with conservation in mind. Ad- 
Table 1. Indices relating to the distribution of taxonomic coverage for and the resolution on the composite tree of various carnivoran taxa. The parenthetical value of per cent resolution for herpestids refers to when safe taxonomic reduction (Wilkinson 1995) was used to improve the resolution of this family (see Fig. 11 B). We refer to the index elements per source tree per taxon as the 'coverage index' in the text

\begin{tabular}{llllll}
\hline \hline Taxon & $\begin{array}{l}\text { Number of } \\
\text { source trees }\end{array}$ & $\begin{array}{l}\text { Number of } \\
\text { elements }\end{array}$ & Per cent resolution & $\begin{array}{l}\text { Elements per } \\
\text { taxon }\end{array}$ & $\begin{array}{l}\text { Elements per } \\
\text { source tree } \\
\text { per taxon }\end{array}$ \\
\hline 'Higher groups' & 62 & 202 & 100.0 & 16.8 & 0.27 \\
Mustelidae & 30 & 155 & 72.7 & 3.4 & 0.11 \\
Lutrinae & 6 & 37 & 75.0 & 2.8 & 0.47 \\
Mephitinae & 5 & 18 & 87.5 & 2.0 & 0.40 \\
Procyonidae & 7 & 27 & 52.9 & 1.5 & 0.21 \\
Otariidae & 15 & 46 & 69.2 & 3.3 & 0.22 \\
Phocidae & 21 & 120 & 94.4 & 6.3 & 0.30 \\
Uridae & 28 & 50 & 85.7 & 6.2 & 0.22 \\
Canidae & 36 & 180 & 69.7 & 5.3 & 0.15 \\
Felidae & 40 & 282 & 97.1 & 7.8 & 0.20 \\
Hyaenidae & 6 & 8 & 66.7 & 2.0 & 0.33 \\
Herpestidae & 9 & 53 & $27.8(55.6)$ & 1.4 & 0.16 \\
Viverridae & 9 & 90 & 97.0 & 2.6 & 0.29 \\
\hline \hline
\end{tabular}

ditionally, researchers have been attracted to groups whose relationships are controversial. Finally, many species that are poorly known systematically are also unstudied with respect to other biological characteristics. It is unsurprising that most of these species are nocturnal, solitary, fast, and have large home ranges, often in poorly inhabited or remote regions (see Gittleman, 1989, 1996).

The groups that have been studied the most often also tend to have the most binary elements per taxon. However, this latter measure does distinguish among the more poorly studied groups, with the herpestids and procyonids lagging behind the rest.

A final measure, the 'coverage index' (i.e. elements per source tree per taxon), reveals how thoroughly a group has been investigated in each study. High values indicate that individual studies have on average examined a large proportion of the constituent taxa (although the number of elements is also determined by the resolution of the source tree). Hyaenids, lutrines, mephitines, and phocids have high coverage indices. Except for the phocids, these groups did not have many source trees. Groups with low coverage indices include the canids, felids, herpestids, and mustelids. Note that a low coverage index does not necessarily imply that only the same few taxa have been examined in each tree (although this is true of herpestids). Given the inherent difficulties in examining a larger number of taxa, it is unsurprising that smaller groups tend to have higher coverage indices than do the larger ones $\left(r^{2}=0.43, P=0.01\right)$.

The numbers for the viverrids are deceptive. This family has generally been poorly studied; however, the complete species-level phylogeny of Wozencraft (1984) obscures this. Without this study, the number of elements for viverrids would drop by over a third and the two ratios would fall to the levels found in other poorly studied taxa. The exclusion would also improve the correlation between the coverage index and the size of the group $\left(r^{2}=0.51, P=0.006\right)$.

\section{(2) Resolution and robustness}

The composite tree (divided among Figs 1-12; presented as a whole in Fig. 13) contains 211 nodes, making it $78.1 \%$ resolved compared to a fully bifurcating solution. Resolution varies among groups, ranging between $27.8 \%$ (herpestids) and $100 \%$ (higher groups) (Table 1). Removing the poorly known herpestid species (see 'Methodology') improves the resolution for this family to $55.6 \%$. Apart from the herpestids, the poorest resolution was for the Procyonidae $(52.9 \%)$. Most groups were at least $70 \%$ resolved, and three (felids, phocids and viverrids) were more than $90 \%$ resolved. However, for the viverrids, the resolution is again due to Wozencraft's (1984) full species-level analysis. If this study were excluded, resolution for the family would fall to $69.7 \%$. 


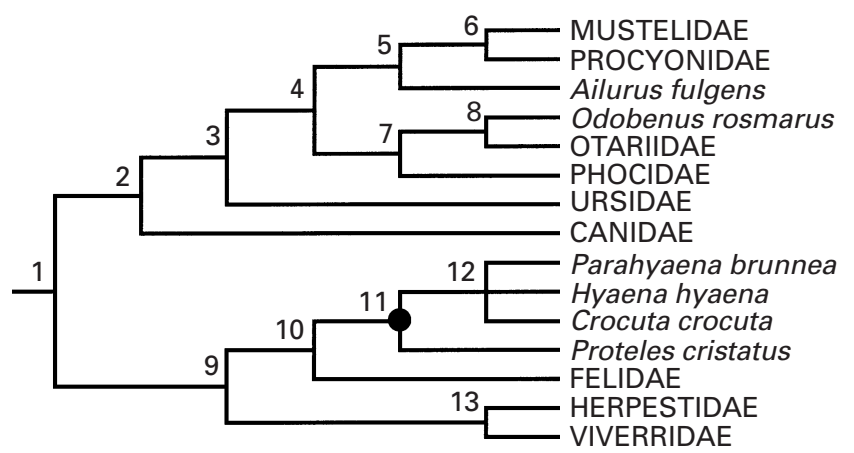

Fig. 1. The composite tree for the higher groups of carnivores plus Hyaenidae (which were assumed to be monophyletic as denoted by the solid circle). Node numbers refer to Table 2. In this and Figs 2-12, branch lengths are not proportional to time. References used as source trees are given in the Appendix.

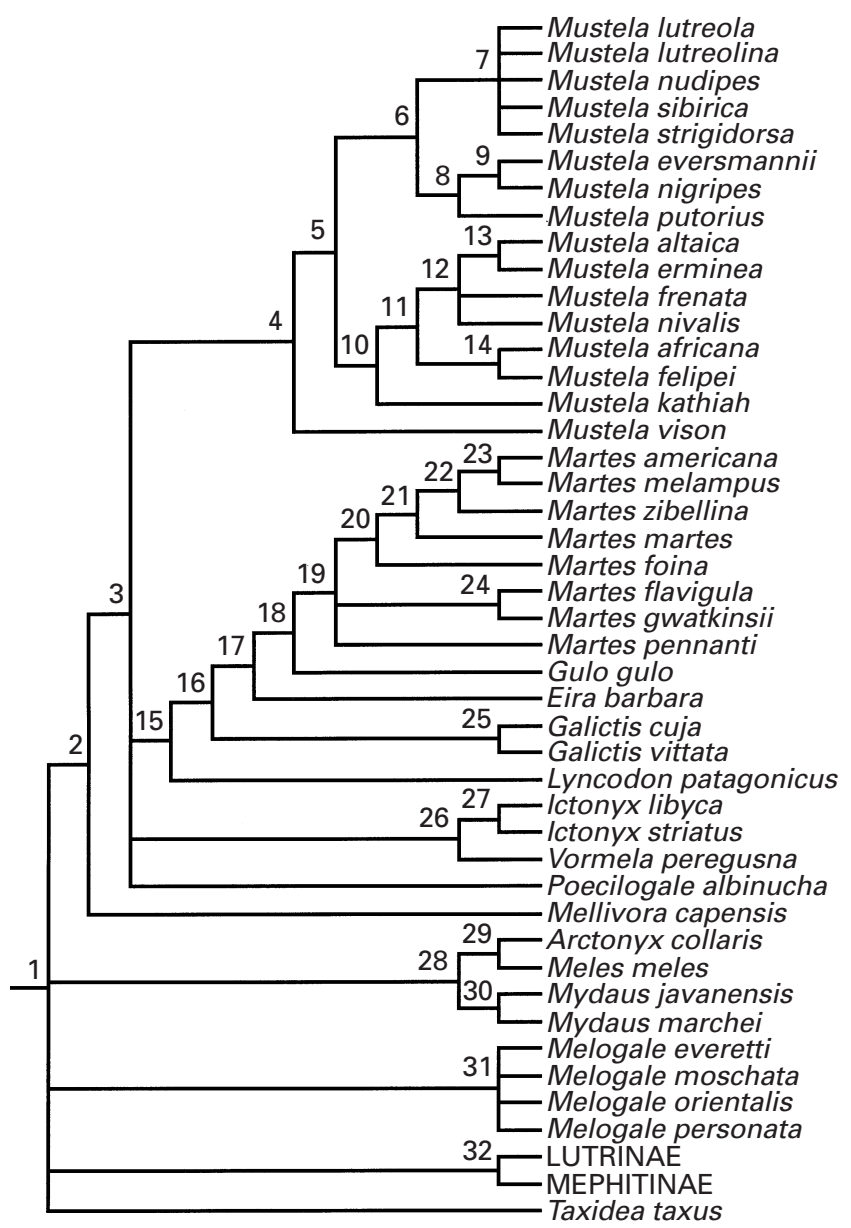

Fig. 2. The composite tree for Mustelidae (exclusive of Lutrinae and Mephitinae). Node numbers refer to Table 3, other details are as in Fig. 1.

The poor resolution for the procyonids is restricted to within the genera Bassaricyon and Procyon and arises not from conflict between the source trees but

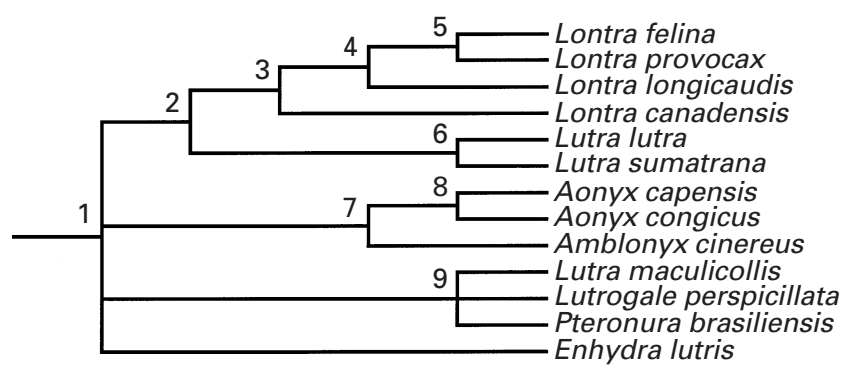

Fig. 3. The composite tree for Lutrinae. Node numbers refer to Table 4, other details are as in Fig. 1.

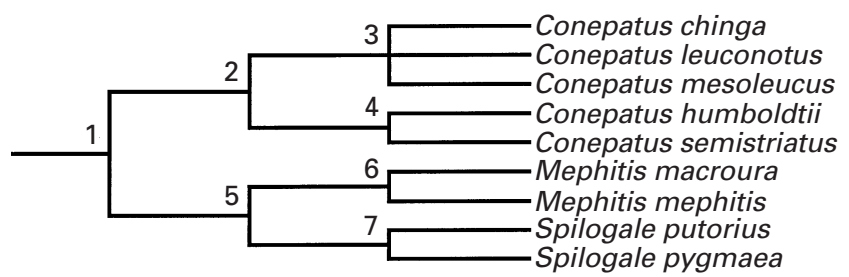

Fig. 4. The composite tree for Mephitinae. Node numbers refer to Table 5, other details are as in Fig. 1.

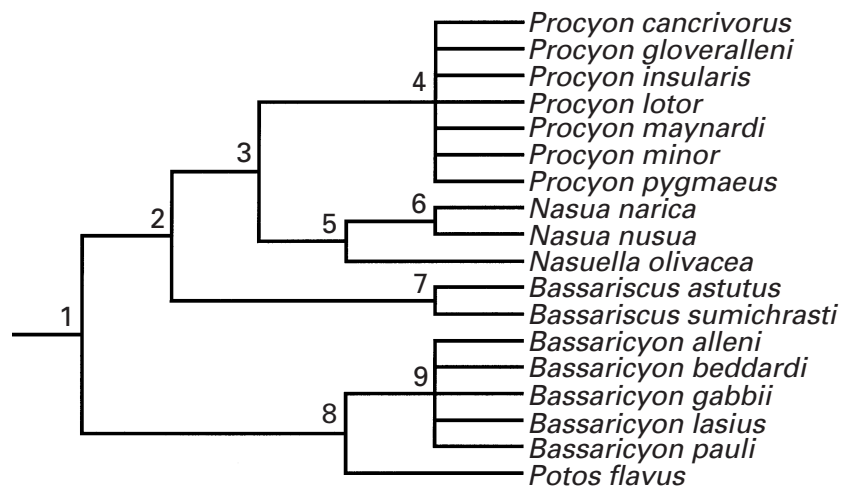

Fig. 5. The composite tree for Procyonidae. Node numbers refer to Table 6, other details are as in Fig. 1.

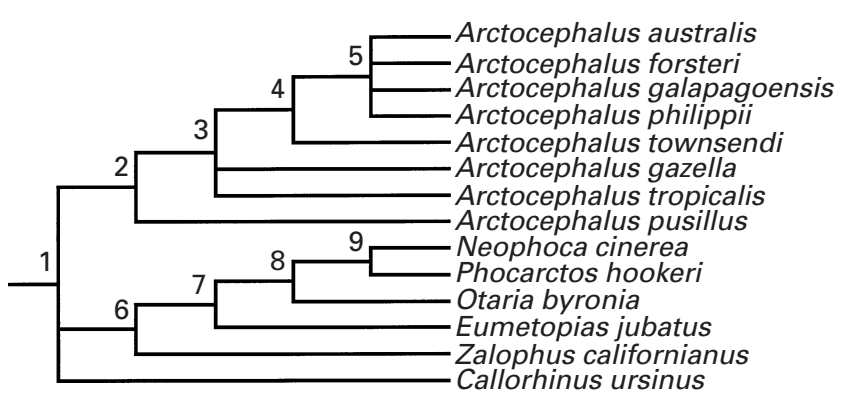

Fig. 6. The composite tree for Otariidae. Node numbers refer to Table 7 , other details are as in Fig. 1.

from a complete lack of information. This may reflect suggestions that there are fewer legitimate species than are currently recognized (e.g. PoglayenNeuwall \& Poglayen-Neuwall, 1965; Lotze \& Anderson, 1979; Hall, 1981; Olson \& Pregill, 1982). 


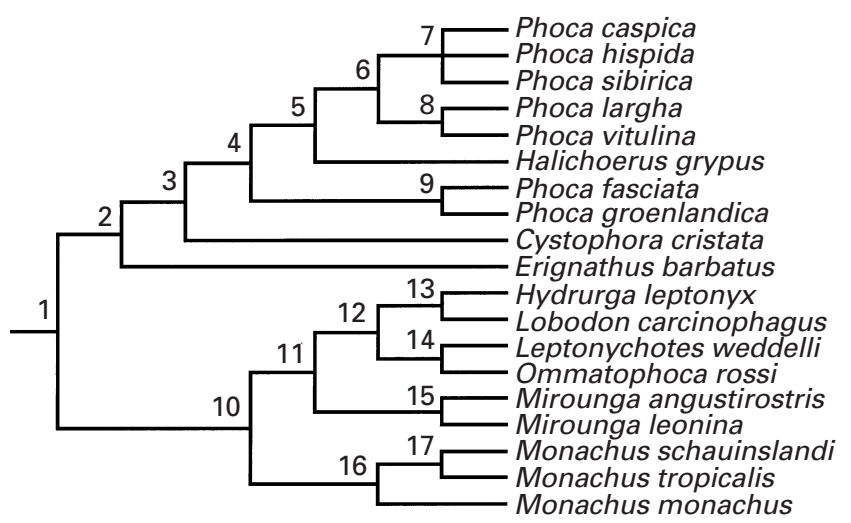

Fig. 7. The composite tree for Phocidae. Node numbers refer to Table 8, other details are as in Fig. 1.

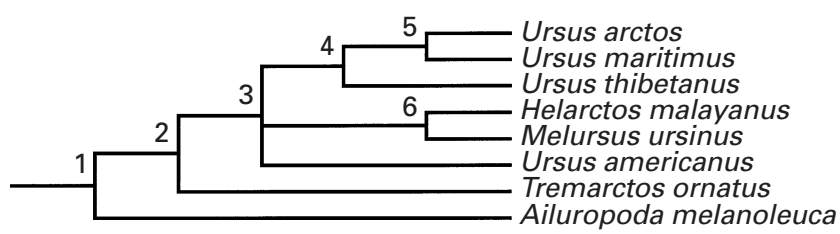

Fig. 8. The composite tree for Ursidae. Node numbers refer to Table 9, other details are as in Fig. 1.

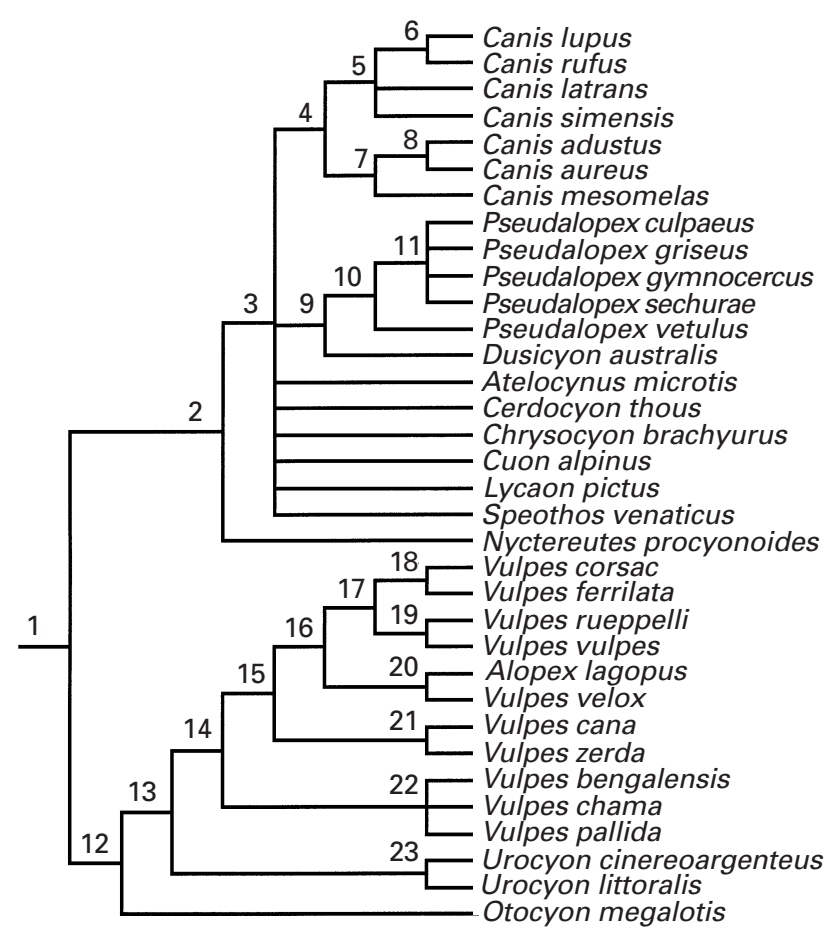

Fig. 9. The composite tree for Canidae. Node numbers refer to Table 10, other details are as in Fig. 1.

Bremer support values differed significantly among groups (Kruskal-Wallis $H=48.4, \quad P<0.0001$; see Tables 2-13). Taxa with large values are the higher groups, hyaenids, phocids, and ursids; only the herpestids display low values. Older nodes

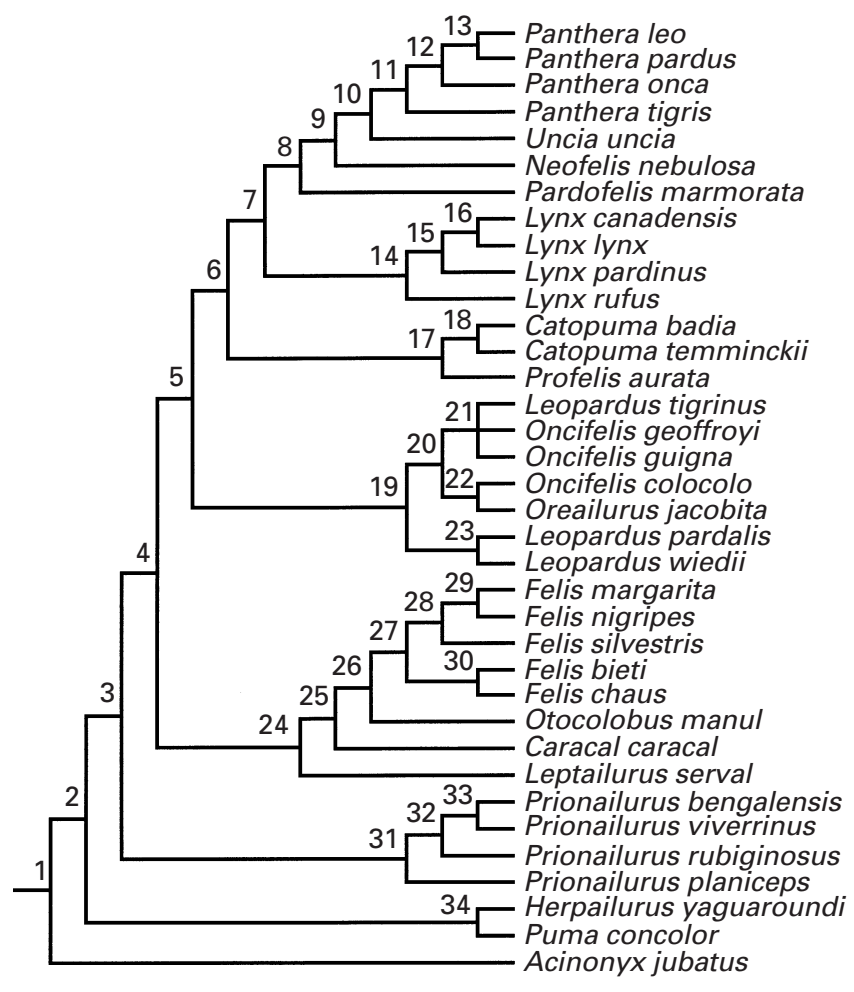

Fig. 10. The composite tree for Felidae. Node numbers refer to Table 11, other details are as in Fig. 1.

tend to show higher Bremer support values $\left(r^{2}=0.17, \quad P<0.0001\right)$ because relationships at these levels are more agreed upon and better studied. Many phylogenies, particularly molecular ones, detail relationships among somewhat distantly related species. This provides information at the older, higher levels, but none for the more closely related sister species that are missing from the analysis.

The differential weighting of source trees according to the data and/or methodology used to obtain them had little impact on the composite tree (Tables 2-13). When more robust source trees (following Purvis, 1995a) were weighted four times as heavily, only 10 of the 211 nodes of the composite tree were contradicted, most often due to a slightly altered position for a single clade (which automatically results in two, non-independent contradictions). Differential weighting also resolved six polytomies within the composite tree. This extra resolution is not surprising given that weighting certain elements essentially amounts to increasing their number within the matrix, which has been demonstrated to increase resolution (Hillis \& Huelsenbeck, 1992; Wheeler, 1992). However, three nodes within the herpestids collapsed under the differential weighting scheme, including the basal 


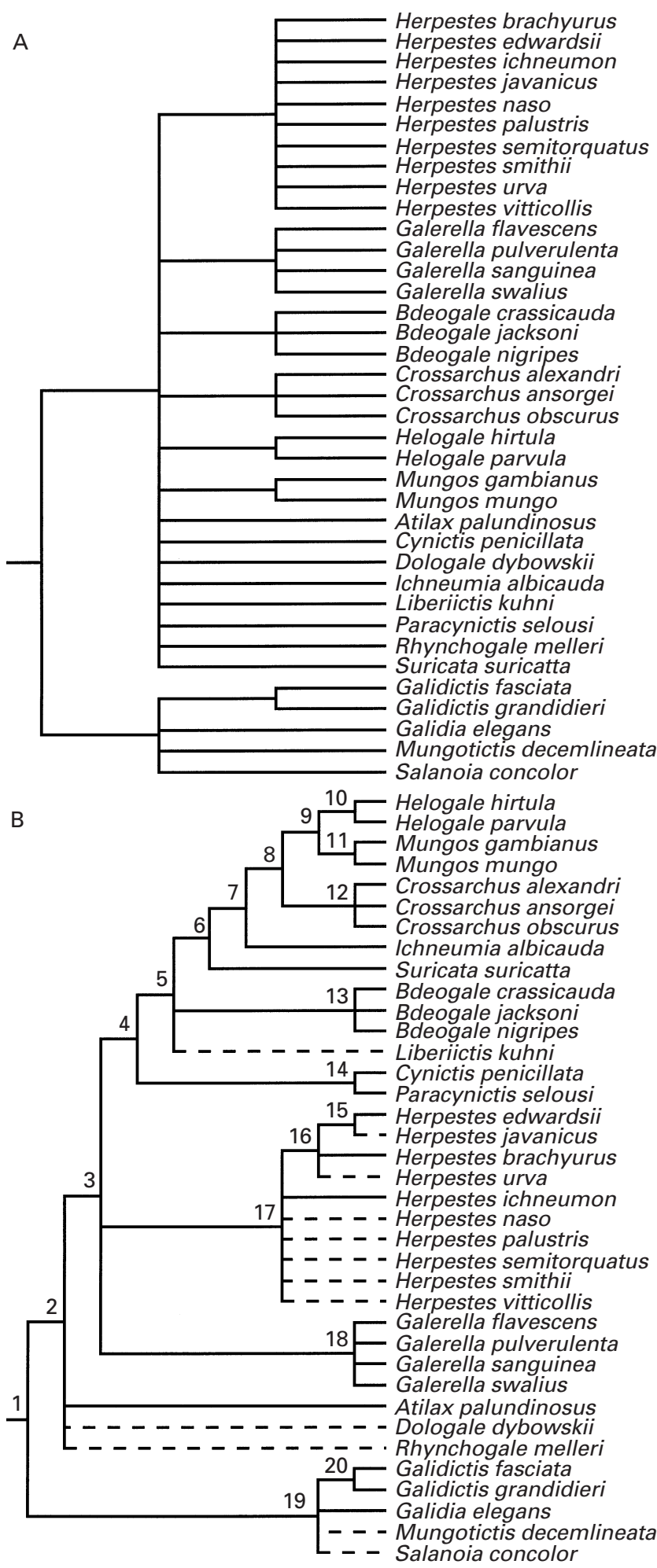

Fig. 11. The composite tree for Herpestidae. (A) Initial analysis of all species. (B) Subsequent analysis in which poorly known species (indicated by a dashed branch) displaying taxonomic equivalence with better known species were excluded from the analysis (following Wilkinson, 1995) and subsequently re-included at the

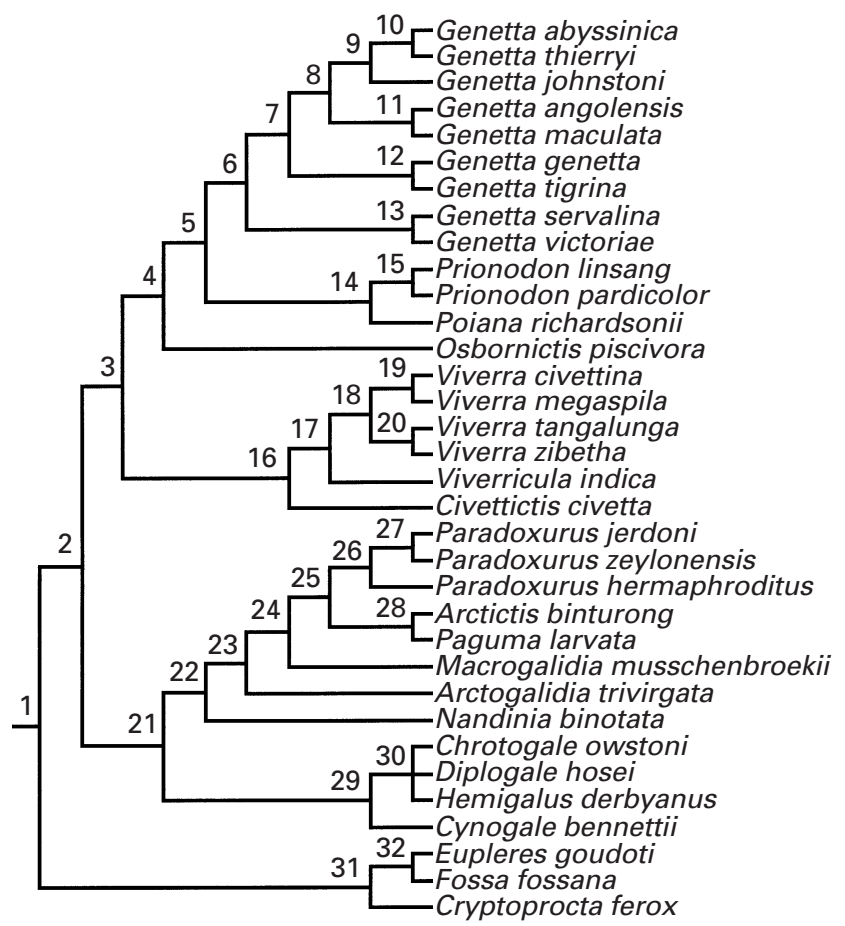

Fig. 12. The composite tree for Viverridae. Node numbers refer to Table 13, other details are as in Fig. 1.

node for Herpestes (Table 12). To summarize, it seems that most source trees are giving the same general pattern of carnivore phylogeny, regardless of the data or methodology used to generate them.

\section{(3) Times of divergence}

Date estimates were obtained from the literature for 150 nodes on the composite tree, 73 of which had at least one estimate from both fossil and molecular sources. Four families plus the higher level relationships had date estimates for every node, with all remaining families except herpestids and viverrids having at least $66 \%$ coverage. For these latter two families, date estimates were only available for eight out of $20(40.0 \%)$ and seven out of $32(21.9 \%)$ nodes, respectively.

Errors in median dates were reasonable, with 'coefficients of variation' (calculated relative to the median and not the mean) exceeding $100 \%$ for only 12 nodes of the 105 that possessed two or more date estimates. Using a one-way analysis of variance of log-transformed dates with node number as the grouping factor (see Purvis, $1995 a$ for more detail), the error for the 45 nodes with only a single date

least inclusive level indicated for them. Node numbers in (B) refer to Table 12, other details are as in Fig. 1. 


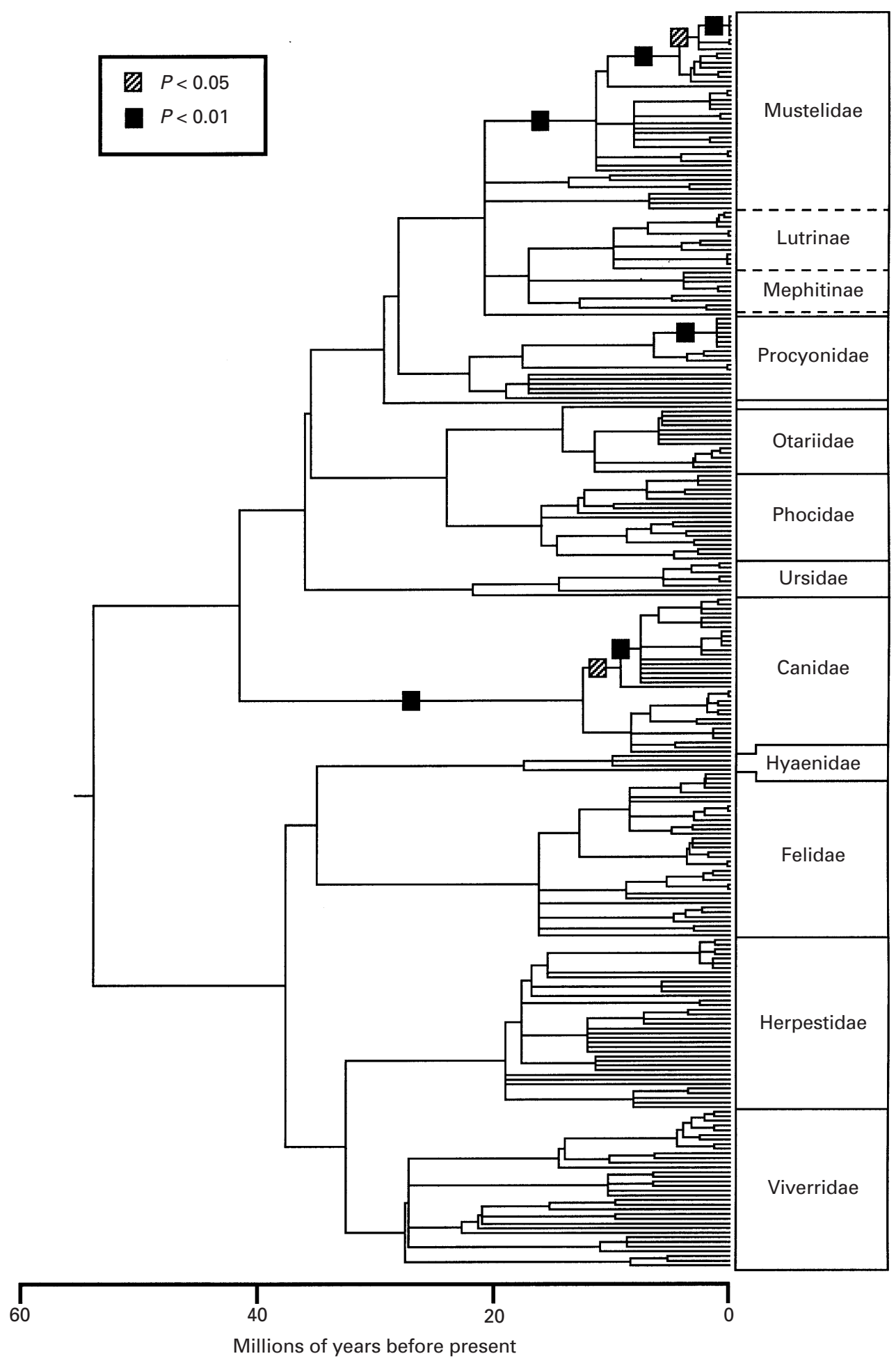

Fig. 13. The composite tree for all 271 extant species of carnivore, including estimated times of divergence and showing which lineages have given rise to significantly more extant descendants than expected (hatched squares: $P<0.05$; filled squares: $P<0.01)$. Within major taxa, species are presented in the same order as in Figs 1-12. Dates were estimated either from the literature (see Tables 2-13) or via a pure birth model. Negative branch lengths are drawn as having zero length. See text for further details. 
Table 2. Statistics relating to the times of divergence of and support for the nodes of the composite tree for the "higher groups' of carnivores plus Hyaenidae (assumed to be monophyletic) (see Fig. 1). All divergence times are in millions of years before present. Both median and mean estimates for a number of date estimates from the literature $(\mathcal{N})$ are presented as is the standard error of the mean (S.E.M.). Dates proportional to the logarithm of the number of species in the clade ('birth model'; see text) are given for nodes without a literature estimate. The best estimate for a node is the literature estimate or, secondarily, the birth model estimate corrected for negative branch lengths. Results for 'differential weighting' refer to whether or not a node was retained when the weighting scheme of Purvis (1995a) was applied.

Unless otherwise indicated, the node was retained unaltered under this alternative weighting scheme

\begin{tabular}{|c|c|c|c|c|c|c|c|c|}
\hline \multirow[b]{2}{*}{ Node } & \multicolumn{4}{|c|}{ Literature estimates } & \multirow{2}{*}{$\begin{array}{l}\text { Birth } \\
\text { model }\end{array}$} & \multirow{2}{*}{$\begin{array}{l}\text { Best } \\
\text { estimate }\end{array}$} & \multirow{2}{*}{$\begin{array}{l}\text { Bremer } \\
\text { support }\end{array}$} & \multirow{2}{*}{$\begin{array}{l}\text { Differential } \\
\text { weighting }\end{array}$} \\
\hline & $\mathcal{N}$ & Median & Mean & S.E.M. & & & & \\
\hline 1 & 6 & 53.8 & 53.6 & 3.1 & - & 53.8 & $\mathrm{n} / \mathrm{a}$ & \\
\hline 2 & 16 & 41.5 & 41.1 & 2.2 & - & 41.5 & 24 & \\
\hline 3 & 14 & 36.0 & 37.1 & 1.7 & - & 36.0 & 13 & \\
\hline 4 & 2 & 35.5 & 35.5 & 0.5 & - & 35.5 & 1 & No \\
\hline 5 & 9 & 29.3 & 27.9 & 2.5 & - & 29.3 & 1 & No \\
\hline 6 & 6 & 28.1 & 29.4 & 2.1 & - & 28.1 & 4 & \\
\hline 7 & 11 & 24.0 & 23.7 & 2.1 & - & 24.0 & 14 & \\
\hline 8 & 5 & 14.2 & 18.2 & 4.8 & - & 14.2 & 9 & \\
\hline 9 & 12 & 37.6 & 35.4 & 2.1 & - & 37.6 & 20 & \\
\hline 10 & 13 & 35.0 & 32.7 & 2.5 & - & 35.0 & 2 & \\
\hline 11 & 3 & 17.5 & 17.5 & 0.0 & - & 17.5 & $\mathrm{n} / \mathrm{a}$ & \\
\hline 12 & 5 & 10.0 & 9.2 & 1.3 & - & 10.0 & 4 & \\
\hline 13 & 9 & 32.5 & 33.8 & 1.4 & - & 32.5 & 4 & \\
\hline
\end{tabular}

estimate was calculated as $\pm 80 \%$. Fortunately, the effect of all these errors on comparative studies should be minimal, given that all estimates are likely to be underestimates and that comparative methods are fairly robust in such cases (Purvis et al., 1994; Purvis, $1995 a$ ).

Generally, nodes with higher 'coefficients of variation' were (1) relatively recent, making any error proportionately larger or (2) those whose dates were derived from very few estimates, allowing a single discrepant estimate to inflate the standard deviation (and hence our reason for using medians rather than means). Naturally, there are exceptions. For example, despite the nodes for the ursine bears (node 3 on Fig. 8), the genus Panthera (node 11 on Fig. 10), and that uniting Alopex lagopus with Vulpes velox (node 20 on Fig. 9) being strongly supported and having dates estimated from a relatively large number of sources (e.g. 17 in the case of the ursine bears), the 'coefficients of variation' in each case exceeded $100 \%$.

Eleven of the 236 molecular estimates were single point estimates and so could not be re-calibrated. The remaining molecular estimates were calibrated against a total of 56 nodes. The nodes used most often for calibration include the basal node for the
Arctoidea (20 estimates), the canid-arctoid divergence (17), the caniform-feliform divergence (15), and the basal nodes for many families (e.g. mustelids, phocids, ursids). Nodes with only a single date estimate (either fossil or molecular) were used as calibration points on only five occasions and none was used to calibrate more than two nodes.

Twenty-two nodes were estimated to be older than an ancestral one (resulting in a negative branch length). In most (15), the difference was less than $100 \%$ of the age of the ancestral node. The largest discrepancy was $770 \%$ (nodes 21 and 22 in the Mustelidae; Fig. 2; Table 3). Felids and mustelids had the largest number of negative branch lengths with six apiece. The basal nodes for felids, herpestids and phocids, upon which molecular estimates within these families largely depend, were indicated to be more recent than a descendent node. The consistency of dates within herpestids and viverrids probably arises from there being very few date estimates for either family.

Negative branch lengths normally arose in one of two ways. First, they were more likely if at least one of the dates was based on three or fewer estimates or was derived from the pure birth model. Such dates tend to have larger confidence intervals, so many of 
Table 3. Statistics relating to the times of divergence of and support for the nodes of the composite tree for Mustelidae (exclusive of Lutrinae and Mephitinae) (see Fig. 2). Other details are as in Table 2

\begin{tabular}{|c|c|c|c|c|c|c|c|c|}
\hline \multirow[b]{2}{*}{ Node } & \multicolumn{4}{|c|}{ Literature estimates } & \multirow{2}{*}{$\begin{array}{l}\text { Birth } \\
\text { model }\end{array}$} & \multirow{2}{*}{$\begin{array}{l}\text { Best } \\
\text { estimate }\end{array}$} & \multirow{2}{*}{$\begin{array}{l}\text { Bremer } \\
\text { support }\end{array}$} & \multirow{2}{*}{$\begin{array}{l}\text { Differential } \\
\text { weighting }\end{array}$} \\
\hline & $\mathcal{N}$ & Median & Mean & S.E.M. & & & & \\
\hline 1 & 10 & 20.8 & 20.8 & 1.5 & - & 20.8 & $\mathrm{n} / \mathrm{a}$ & Resolved \\
\hline 2 & 2 & 8.2 & 8.2 & 0.0 & - & 11.4 & 2 & \\
\hline 3 & 6 & 14.6 & 13.6 & 1.8 & - & 11.4 & 2 & \\
\hline 4 & 3 & 10.4 & 10.7 & 2.0 & - & 10.4 & 3 & \\
\hline 5 & 5 & 4.4 & 5.5 & 1.4 & - & 4.4 & 3 & \\
\hline 6 & 2 & 2.8 & 2.8 & 0.7 & - & 2.8 & 1 & \\
\hline 7 & 1 & 0.2 & 0.2 & - & - & 0.2 & 1 & \\
\hline 8 & 4 & 2.8 & 3.0 & 1.3 & - & 2.8 & 4 & \\
\hline 9 & 3 & 0.2 & 0.5 & 0.3 & - & 0.2 & 3 & \\
\hline 10 & 0 & - & - & - & 3.4 & 3.4 & 1 & \\
\hline 11 & 0 & - & - & - & 3.1 & 3.1 & 1 & \\
\hline 12 & 4 & 2.6 & 2.5 & 0.6 & - & 2.6 & 1 & No \\
\hline 13 & 1 & 1.2 & 1.2 & - & - & 1.2 & 1 & \\
\hline 14 & 0 & - & - & - & 1.1 & 1.1 & 2 & \\
\hline 15 & 0 & - & - & - & 6.9 & 8.2 & 3 & \\
\hline 16 & 0 & - & - & - & 6.7 & 8.2 & 1 & \\
\hline 17 & 0 & - & - & - & 6.2 & 8.2 & 1 & \\
\hline 18 & 1 & 2.6 & 2.6 & - & - & 8.2 & 1 & \\
\hline 19 & 2 & 18.7 & 18.7 & 4.2 & - & 8.2 & 6 & \\
\hline 20 & 3 & 0.2 & 0.5 & 0.4 & - & 1.8 & 1 & \\
\hline 21 & 2 & 0.6 & 0.6 & 0.4 & - & 1.8 & 1 & \\
\hline 22 & 2 & 4.8 & 4.8 & 4.1 & - & 1.8 & 1 & \\
\hline 23 & 1 & 0.3 & 0.3 & - & - & 0.3 & 1 & \\
\hline 24 & 1 & 0.9 & 0.9 & - & - & 0.9 & 1 & \\
\hline 25 & 1 & 1.8 & 1.8 & - & - & 1.8 & 4 & \\
\hline 26 & 1 & 4.2 & 4.2 & - & - & 4.2 & 1 & \\
\hline 27 & 1 & 0.3 & 0.3 & - & - & 0.3 & 1 & \\
\hline 28 & 0 & - & - & - & 13.7 & 13.7 & 1 & \\
\hline 29 & 2 & 10.2 & 10.2 & 2.1 & - & 10.2 & 3 & \\
\hline 30 & 0 & - & - & - & 3.5 & 3.5 & 6 & \\
\hline 31 & 0 & - & - & - & 6.9 & 6.9 & 3 & \\
\hline 32 & 2 & 14.9 & 14.9 & 3.6 & - & 17.1 & 4 & \\
\hline
\end{tabular}

the negative branch lengths are simply overlapping regions of uncertainty. The second way applies only to dates derived from fossil information and occurs when a well-recognized clade, believed to be relatively ancient, is in a fairly terminal position within the phylogeny. Some taxa with good fossil records were indicated to have (frequently monotypic) sister groups with a poor one. Therefore, divergence times will be underestimates when taken to be the time of first occurrence of the apparently much younger sister group. This problem is exacerbated if the crown clade of an ancient lineage has diversified only recently. Dates obtained solely from molecular sources frequently resolved the inconsistency; however, such estimates were not always available.

\section{(4) Fossil versus molecular dates}

Are fossil and molecular estimates of divergence times similar? Wayne et al. (1991) showed that molecular distance data are highly correlated with fossil estimates of divergence time within carnivores and primates. However, fossil and molecular estimates could be highly correlated and yet still differ systematically. We examined this possibility by considering the 73 nodes that possessed at least one estimate from both fossil and molecular sources. 
Table 4. Statistics relating to the times of divergence of and support for the nodes of the composite tree for Lutrinae (see Fig. 3). Other details are as in Table 2

\begin{tabular}{|c|c|c|c|c|c|c|c|c|}
\hline \multirow[b]{2}{*}{ Node } & \multicolumn{4}{|c|}{ Literature estimates } & \multirow{2}{*}{$\begin{array}{l}\text { Birth } \\
\text { model }\end{array}$} & \multirow{2}{*}{$\begin{array}{l}\text { Best } \\
\text { estimate }\end{array}$} & \multirow{2}{*}{$\begin{array}{l}\text { Bremer } \\
\text { support }\end{array}$} & \multirow{2}{*}{$\begin{array}{l}\text { Differentia } \\
\text { weighting }\end{array}$} \\
\hline & $\mathcal{N}$ & Median & Mean & S.E.M. & & & & \\
\hline 1 & 2 & 9.9 & 9.9 & 1.7 & - & 9.9 & $\mathrm{n} / \mathrm{a}$ & Resolved \\
\hline 2 & 1 & 7.0 & 7.0 & - & - & 7.0 & 1 & \\
\hline 3 & 1 & 1.2 & 1.2 & - & - & 1.2 & 6 & \\
\hline 4 & 0 & - & - & - & 1.0 & 1.0 & 1 & \\
\hline 5 & 0 & - & - & - & 0.6 & 0.6 & 1 & \\
\hline 6 & 1 & 0.2 & 0.2 & - & - & 0.2 & 2 & \\
\hline 7 & 0 & - & - & - & 4.2 & 4.2 & 3 & \\
\hline 8 & 1 & 2.6 & 2.6 & - & - & 2.6 & 4 & \\
\hline 9 & 1 & 0.3 & 0.3 & - & - & 0.3 & 1 & Resolved \\
\hline
\end{tabular}

Table 5. Statistics relating to the times of divergence of and support for the nodes of the composite tree for Mephitinae (see Fig. 4). Other details are as in Table 2

\begin{tabular}{|c|c|c|c|c|c|c|c|c|}
\hline \multirow[b]{2}{*}{ Node } & \multicolumn{4}{|c|}{ Literature estimates } & \multirow{2}{*}{$\begin{array}{l}\text { Birth } \\
\text { model }\end{array}$} & \multirow{2}{*}{$\begin{array}{l}\text { Best } \\
\text { estimate }\end{array}$} & \multirow{2}{*}{$\begin{array}{l}\text { Bremer } \\
\text { support }\end{array}$} & \multirow{2}{*}{$\begin{array}{l}\text { Differential } \\
\text { weighting }\end{array}$} \\
\hline & $\mathcal{N}$ & Median & Mean & S.E.M. & & & & \\
\hline 1 & 3 & 19.2 & 17.6 & 1.8 & - & 17.1 & $\mathrm{n} / \mathrm{a}$ & \\
\hline 2 & 1 & 2.6 & 2.6 & - & - & 4.0 & 2 & \\
\hline 3 & 3 & 5.5 & 4.7 & 1.8 & - & 4.0 & 1 & \\
\hline 4 & 0 & - & - & - & 1.1 & 1.1 & 1 & \\
\hline 5 & 5 & 12.8 & 11.4 & 3.0 & - & 12.8 & 1 & \\
\hline 6 & 4 & 5.0 & 5.5 & 2.0 & - & 5.0 & 4 & \\
\hline 7 & 2 & 2.1 & 2.1 & 0.9 & - & 2.1 & 2 & \\
\hline
\end{tabular}

Table 6. Statistics relating to the times of divergence of and support for the nodes of the composite tree for Procyonidae (Fig. 5). Other details are as in Table 2

\begin{tabular}{|c|c|c|c|c|c|c|c|c|}
\hline \multirow[b]{2}{*}{ Node } & \multicolumn{4}{|c|}{ Literature estimates } & \multirow{2}{*}{$\begin{array}{l}\text { Birth } \\
\text { model }\end{array}$} & \multirow{2}{*}{$\begin{array}{l}\text { Best } \\
\text { estimate }\end{array}$} & \multirow{2}{*}{$\begin{array}{l}\text { Bremer } \\
\text { support }\end{array}$} & \multirow{2}{*}{$\begin{array}{l}\text { Differential } \\
\text { weighting }\end{array}$} \\
\hline & $\mathcal{N}$ & Median & Mean & S.E.M. & & & & \\
\hline 1 & 2 & 22.1 & 22.1 & 0.8 & - & 22.1 & $\mathrm{n} / \mathrm{a}$ & \\
\hline 2 & 4 & 17.6 & 17.1 & 1.0 & - & 17.6 & 2 & \\
\hline 3 & 3 & 6.5 & 6.0 & 0.5 & - & 6.5 & 2 & \\
\hline 4 & 1 & 1.2 & 1.2 & - & - & 1.2 & 3 & \\
\hline 5 & 1 & 3.7 & 3.7 & - & - & 3.7 & 1 & \\
\hline 6 & 0 & - & - & - & 2.3 & 2.3 & 2 & \\
\hline 7 & 1 & 0.3 & 0.3 & - & - & 0.3 & 3 & \\
\hline 8 & 1 & 19.0 & 19.0 & - & - & 19.0 & 1 & \\
\hline 9 & 0 & - & - & - & 17.1 & 17.1 & 5 & \\
\hline
\end{tabular}

Initial results gave a weakly significant difference (paired $t$ of log-transformed dates $=-2.21, P=$ $0.03)$. However, this finding depends upon how the molecular estimates are calibrated. In the above case, we used two (absolute) molecular estimates of the time of the caniform-feliform divergence. One 
Table 7. Statistics relating to the times of divergence of and support for the nodes of the composite tree for Otariidae (see Fig. 6). Other details are as in Table 2

\begin{tabular}{|c|c|c|c|c|c|c|c|c|}
\hline \multirow[b]{2}{*}{ Node } & \multicolumn{4}{|c|}{ Literature estimates } & \multirow{2}{*}{$\begin{array}{l}\text { Birth } \\
\text { model }\end{array}$} & \multirow{2}{*}{$\begin{array}{l}\text { Best } \\
\text { estimate }\end{array}$} & \multirow{2}{*}{$\begin{array}{l}\text { Bremer } \\
\text { support }\end{array}$} & \multirow{2}{*}{$\begin{array}{l}\text { Differential } \\
\text { weighting }\end{array}$} \\
\hline & $\mathcal{N}$ & Median & Mean & S.E.M. & & & & \\
\hline 1 & 7 & 11.5 & 11.5 & 1.1 & - & 11.5 & $\mathrm{n} / \mathrm{a}$ & \\
\hline 2 & 3 & 3.4 & 3.8 & 0.6 & - & 6.1 & 5 & \\
\hline 3 & 1 & 8.1 & 8.1 & - & - & 6.1 & 1 & \\
\hline 4 & 0 & - & - & - & 6.7 & 6.1 & 1 & \\
\hline 5 & 0 & - & - & - & 5.8 & 5.8 & 1 & \\
\hline 6 & 6 & 3.2 & 4.7 & 1.1 & - & 3.2 & 8 & \\
\hline 7 & 3 & 3.0 & 3.0 & 0.3 & - & 3.0 & 5 & \\
\hline 8 & 2 & 1.6 & 1.6 & 0.2 & - & 1.6 & 3 & \\
\hline 9 & 2 & 0.9 & 0.9 & 0.4 & - & 0.9 & 1 & No \\
\hline
\end{tabular}

Table 8. Statistics relating to the times of divergence of and support for the nodes of the composite tree for Phocidae (see Fig. 7). Other details are as in Table 2

\begin{tabular}{|c|c|c|c|c|c|c|c|c|}
\hline \multirow[b]{2}{*}{ Node } & \multicolumn{4}{|c|}{ Literature estimates } & \multirow{2}{*}{$\begin{array}{l}\text { Birth } \\
\text { model }\end{array}$} & \multirow{2}{*}{$\begin{array}{l}\text { Best } \\
\text { estimate }\end{array}$} & \multirow{2}{*}{$\begin{array}{l}\text { Bremer } \\
\text { support }\end{array}$} & \multirow{2}{*}{$\begin{array}{l}\text { Differential } \\
\text { weighting }\end{array}$} \\
\hline & $\mathcal{N}$ & Median & Mean & S.E.M. & & & & \\
\hline 1 & 11 & 15.0 & 14.4 & 0.7 & - & 16.0 & $\mathrm{n} / \mathrm{a}$ & \\
\hline 2 & 4 & 17.0 & 17.7 & 2.2 & - & 16.0 & 6 & \\
\hline 3 & 2 & 12.9 & 12.9 & 0.1 & - & 12.9 & 3 & \\
\hline 4 & 3 & 12.4 & 11.8 & 0.7 & - & 12.4 & 6 & \\
\hline 5 & 4 & 5.6 & 5.8 & 0.3 & - & 7.1 & 3 & \\
\hline 6 & 4 & 8.6 & 8.0 & 2.6 & - & 7.1 & 1 & \\
\hline 7 & 1 & 2.8 & 2.8 & - & - & 2.8 & 4 & Resolved \\
\hline 8 & 2 & 3.9 & 3.9 & 0.5 & - & 3.9 & 4 & \\
\hline 9 & 1 & 9.9 & 9.9 & - & - & 9.9 & 9 & \\
\hline 10 & 5 & 14.7 & 14.7 & 0.1 & - & 14.7 & 4 & \\
\hline 11 & 7 & 8.8 & 8.7 & 1.6 & - & 8.8 & 1 & \\
\hline 12 & 5 & 6.7 & 7.2 & 1.3 & - & 6.7 & 7 & \\
\hline 13 & 1 & 4.9 & 4.9 & - & - & 4.9 & 1 & \\
\hline 14 & 2 & 3.8 & 3.8 & 0.7 & - & 3.8 & 2 & \\
\hline 15 & 3 & 3.1 & 3.0 & 0.3 & - & 3.1 & 8 & \\
\hline 16 & 1 & 4.8 & 4.8 & - & - & 4.8 & 8 & \\
\hline 17 & 1 & 2.8 & 2.8 & - & - & 2.8 & 2 & \\
\hline
\end{tabular}

estimate [52.0 million years before present (MYBP); Sarich, 1969b] was derived from an albumin clock calibrated with primate data while the other (40.6 MYBP; Goodman et al., 1982) used a molecular clock of many different proteins calibrated using an estimate of 90 MYBP for the common ancestor of all extant eutherian mammals. Thus, the average calibration point (46.3 MYBP) was independent of the carnivore fossil record. This does not seem appropriate given that different lineages evolve at different rates (Gillespie, 1991; Wayne et al., 1991;
Flynn, 1996) and any rate anomalies peculiar to the carnivores would therefore likely be missed.

When the molecular estimates are calibrated against the carnivore fossil record (using the median estimate of 55.0 MYBP obtained from the fossil sources), they now clearly provide significantly older estimates (paired $t$ of log-transformed dates $=-3.71$, $P=0.0004)$. This seems reasonable given that fossil estimates will nearly always be underestimates of the true time of divergence (Marshall, 1990; Flynn, 1996). We add that although both differences are 
Table 9. Statistics relating to the times of divergence of and support for the nodes of the composite tree for Ursidae (see Fig. 8). Other details are as in Table 2

\begin{tabular}{|c|c|c|c|c|c|c|c|c|}
\hline \multirow[b]{2}{*}{ Node } & \multicolumn{4}{|c|}{ Literature estimates } & \multirow{2}{*}{$\begin{array}{l}\text { Birth } \\
\text { model }\end{array}$} & \multirow{2}{*}{$\begin{array}{l}\text { Best } \\
\text { estimate }\end{array}$} & \multirow{2}{*}{$\begin{array}{l}\text { Bremer } \\
\text { support }\end{array}$} & \multirow{2}{*}{$\begin{array}{l}\text { Differential } \\
\text { weighting }\end{array}$} \\
\hline & $\mathcal{N}$ & Median & Mean & S.E.M. & & & & \\
\hline 1 & 13 & 21.8 & 21.5 & 2.5 & - & 21.8 & $\mathrm{n} / \mathrm{a}$ & \\
\hline 2 & 17 & 14.5 & 13.1 & 1.1 & - & 14.5 & 13 & \\
\hline 3 & 17 & 5.7 & 8.6 & 1.7 & - & 5.7 & 9 & Resolved \\
\hline 4 & 6 & 3.3 & 3.4 & 0.7 & - & 3.3 & 2 & \\
\hline 5 & 12 & 1.0 & 1.2 & 0.3 & - & 1.0 & 3 & \\
\hline 6 & 3 & 1.0 & 4.7 & 3.8 & - & 1.0 & 1 & \\
\hline
\end{tabular}

Table 10. Statistics relating to the times of divergence of and support for the nodes of the composite tree for Canidae (see Fig. 9). Other details are as in Table 2

\begin{tabular}{|c|c|c|c|c|c|c|c|c|}
\hline \multirow[b]{2}{*}{ Node } & \multicolumn{4}{|c|}{ Literature estimates } & \multirow{2}{*}{$\begin{array}{l}\text { Birth } \\
\text { model }\end{array}$} & \multirow{2}{*}{$\begin{array}{l}\text { Best } \\
\text { estimate }\end{array}$} & \multirow{2}{*}{$\begin{array}{l}\text { Bremer } \\
\text { support }\end{array}$} & \multirow{2}{*}{$\begin{array}{l}\text { Differential } \\
\text { weighting }\end{array}$} \\
\hline & $\mathcal{N}$ & Median & Mean & S.E.M. & & & & \\
\hline 1 & 5 & 12.5 & 15.1 & 3.5 & - & 12.5 & $\mathrm{n} / \mathrm{a}$ & \\
\hline 2 & 2 & 9.3 & 9.3 & 2.3 & - & 9.3 & 1 & \\
\hline 3 & 6 & 7.6 & 7.3 & 0.6 & - & 7.6 & 3 & \\
\hline 4 & 8 & 6.1 & 6.5 & 0.9 & - & 6.1 & 10 & \\
\hline 5 & 11 & 2.5 & 2.5 & 0.3 & - & 2.5 & 2 & \\
\hline 6 & 4 & 1.1 & 1.0 & 0.3 & - & 1.1 & 2 & \\
\hline 7 & 3 & 2.5 & 2.6 & 0.4 & - & 2.5 & 2 & \\
\hline 8 & 3 & 2.5 & 2.2 & 1.0 & - & 2.5 & 1 & \\
\hline 9 & 3 & 2.5 & 2.1 & 0.4 & - & 2.5 & 1 & \\
\hline 10 & 1 & 2.5 & 2.5 & - & - & 2.5 & 1 & \\
\hline 11 & 2 & 0.8 & 0.8 & 0.4 & - & 0.8 & 1 & \\
\hline 12 & 2 & 7.0 & 7.0 & 4.4 & - & 8.4 & 3 & \\
\hline 13 & 1 & 8.2 & 8.2 & - & - & 8.4 & 1 & \\
\hline 14 & 2 & 10.1 & 10.1 & 0.2 & - & 8.4 & 6 & \\
\hline 15 & 3 & 6.8 & 6.8 & 2.3 & - & 6.8 & 1 & \\
\hline 16 & 3 & 2.0 & 3.2 & 1.6 & - & 2.0 & 1 & \\
\hline 17 & 1 & 1.9 & 1.9 & - & - & 1.9 & 1 & \\
\hline 18 & 1 & 0.2 & 0.2 & - & - & 0.2 & 1 & \\
\hline 19 & 4 & 1.1 & 2.4 & 1.7 & - & 1.1 & 1 & \\
\hline 20 & 6 & 1.1 & 1.8 & 0.7 & - & 1.1 & 1 & \\
\hline 21 & 4 & 2.9 & 3.4 & 1.7 & - & 2.9 & 1 & \\
\hline 22 & 2 & 1.5 & 1.5 & 0.0 & - & 1.5 & 1 & \\
\hline 23 & 4 & 4.7 & 4.5 & 1.3 & - & 4.7 & 7 & \\
\hline
\end{tabular}

significant, they are small. Back-transforming shows the mean difference in dates between the two sources to be either 1.3 or 1.5 million years, depending on the calibration point used. In approximately a third of the cases, these values are smaller than the standard errors associated with either data source for a given node (results not shown).

The discrepancy between the two tests stems from
Goodman et al.'s (1982) date for the divergence of the (extant) carnivores being substantially more recent than both Sarich's $(1969 b)$ and the fossil estimate. This arises from their use of a calibration point of 90 MYBP for the origin of the extant eutherians, a figure now held to be at least 30 million years too recent (Graur, 1993; U. Arnason, personal communication). Although we used the orig- 
Table 11. Statistics relating to the times of divergence of and support for the nodes of the composite tree for Felidae (see Fig. 10). Other details are as in Table 2

\begin{tabular}{|c|c|c|c|c|c|c|c|c|}
\hline \multirow[b]{2}{*}{ Node } & \multicolumn{4}{|c|}{ Literature estimates } & \multirow{2}{*}{$\begin{array}{l}\text { Birth } \\
\text { model }\end{array}$} & \multirow{2}{*}{$\begin{array}{l}\text { Best } \\
\text { estimate }\end{array}$} & \multirow{2}{*}{$\begin{array}{l}\text { Bremer } \\
\text { support }\end{array}$} & \multirow{2}{*}{$\begin{array}{l}\text { Differential } \\
\text { weighting }\end{array}$} \\
\hline & $\mathcal{N}$ & Median & Mean & S.E.M. & & & & \\
\hline 1 & 8 & 12.5 & 14.1 & 2.4 & - & 16.2 & $\mathrm{n} / \mathrm{a}$ & \\
\hline 2 & 0 & - & - & - & 15.4 & 16.2 & 2 & No \\
\hline 3 & 0 & - & - & - & 16.6 & 16.2 & 1 & No \\
\hline 4 & 3 & 20.2 & 20.9 & 7.6 & - & 16.2 & 1 & \\
\hline 5 & 2 & 12.8 & 12.8 & 1.2 & - & 12.8 & 1 & \\
\hline 6 & 1 & 7.3 & 7.3 & - & - & 8.5 & 1 & \\
\hline 7 & 2 & 5.4 & 5.4 & 1.1 & - & 8.5 & 7 & \\
\hline 8 & 1 & 10.6 & 10.6 & - & - & 8.5 & 2 & No \\
\hline 9 & 2 & 10.6 & 10.6 & 1.7 & - & 8.5 & 3 & \\
\hline 10 & 2 & 4.2 & 4.2 & 0.0 & - & 4.2 & 8 & \\
\hline 11 & 8 & 2.2 & 3.8 & 1.7 & - & 2.2 & 4 & \\
\hline 12 & 5 & 1.5 & 1.8 & 0.3 & - & 2.1 & 3 & \\
\hline 13 & 7 & 2.6 & 2.5 & 0.7 & - & 2.1 & 2 & \\
\hline 14 & 5 & 3.1 & 3.1 & 0.3 & - & 3.1 & 14 & \\
\hline 15 & 1 & 2.2 & 2.2 & - & - & 2.2 & 1 & \\
\hline 16 & 3 & 0.2 & 0.2 & 0.0 & - & 0.2 & 1 & \\
\hline 17 & 1 & 5.0 & 5.0 & - & - & 5.0 & 2 & \\
\hline 18 & 0 & - & - & - & 3.2 & 3.2 & 4 & \\
\hline 19 & 6 & 3.7 & 4.9 & 1.4 & - & 3.7 & 7 & \\
\hline 20 & 2 & 3.5 & 3.5 & 0.1 & - & 3.5 & 5 & \\
\hline 21 & 1 & 3.2 & 3.2 & - & - & 3.2 & 3 & Resolved \\
\hline 22 & 2 & 1.9 & 1.9 & 0.1 & - & 1.9 & 1 & \\
\hline 23 & 3 & 0.3 & 0.6 & 0.4 & - & 0.3 & 9 & \\
\hline 24 & 1 & 16.5 & 16.5 & - & - & 16.2 & 3 & No \\
\hline 25 & 2 & 3.3 & 3.3 & 0.8 & - & 8.8 & 1 & \\
\hline 26 & 3 & 14.4 & 13.6 & 1.9 & - & 8.8 & 3 & \\
\hline 27 & 4 & 5.4 & 6.3 & 1.8 & - & 5.4 & 1 & \\
\hline 28 & 4 & 2.3 & 2.5 & 0.5 & - & 2.3 & 1 & \\
\hline 29 & 0 & - & - & - & 1.5 & 1.5 & 2 & \\
\hline 30 & 2 & 0.2 & 0.2 & 0.1 & - & 0.2 & 1 & \\
\hline 31 & 0 & - & - & - & 4.8 & 4.8 & 3 & \\
\hline 32 & 0 & - & - & - & 3.8 & 3.8 & 2 & \\
\hline 33 & 0 & - & - & - & 2.4 & 2.4 & 2 & \\
\hline 34 & 4 & 3.1 & 2.7 & 0.5 & - & 3.1 & 4 & \\
\hline
\end{tabular}

inal date estimate for the divergence of the carnivores advocated by Goodman et al. (1982), it is interesting that using the currently held value of 120 MYBP for the calibration point shifts Goodman et al.'s (1982) value to $54.1 \mathrm{MYBP}$ in agreement with the other estimates. At the very least, this highlights the importance of using an accurate calibration point to derive divergence times using molecular data.

\section{(5) Systematic implications}

Detailed comments concerning all proposed relation- ships specified by the composite tree are beyond the scope of this review. Instead, we highlight some results in areas of particular historical interest. The composite tree is merely a (most parsimonious) synthesis of a number of source trees; therefore, direct evidence supporting (or refuting) particular relationships on the composite tree should be sought from the original references.

Among the higher groups (Fig. 1), two longstanding areas of contention concern the relationships of the red panda (Ailurus fulgens) and those of the pinnipeds. The composite tree places Ailurus fulgens as the sister group to the clade of mustelids 
Table 12. Statistics relating to the times of divergence of and support for the nodes of the composite tree for Herpestidae (see Fig. $11 \mathrm{~B}$ ). Other details are as in Table 2

\begin{tabular}{|c|c|c|c|c|c|c|c|c|}
\hline \multirow[b]{2}{*}{ Node } & \multicolumn{4}{|c|}{ Literature estimates } & \multirow{2}{*}{$\begin{array}{l}\text { Birth } \\
\text { model }\end{array}$} & \multirow{2}{*}{$\begin{array}{l}\text { Best } \\
\text { estimate }\end{array}$} & \multirow{2}{*}{$\begin{array}{l}\text { Bremer } \\
\text { support }\end{array}$} & \multirow{2}{*}{$\begin{array}{l}\text { Differential } \\
\text { weighting }\end{array}$} \\
\hline & $\mathcal{N}$ & Median & Mean & S.E.M. & & & & \\
\hline 1 & 1 & 18.5 & 18.5 & - & 一 & 19.0 & $\mathrm{n} / \mathrm{a}$ & \\
\hline 2 & 1 & 19.6 & 19.6 & - & - & 19.0 & 2 & \\
\hline 3 & 2 & 17.6 & 17.6 & 0.1 & - & 17.7 & 0 & Collapsed \\
\hline 4 & 0 & - & - & - & 17.8 & 17.7 & 0 & Collapsed \\
\hline 5 & 0 & - & - & - & 16.9 & 16.9 & 0 & \\
\hline 6 & 0 & - & - & - & 14.5 & 15.5 & 0 & \\
\hline 7 & 1 & 16.5 & 16.5 & - & - & 15.5 & 0 & \\
\hline 8 & 1 & 2.6 & 2.6 & - & - & 2.6 & 0 & \\
\hline 9 & 1 & 2.6 & 2.6 & - & - & 2.6 & 0 & \\
\hline 10 & 0 & - & - & - & 1.3 & 1.3 & 1 & \\
\hline 11 & 0 & - & - & - & 1.3 & 1.3 & 1 & \\
\hline 12 & 0 & - & - & - & 1.5 & 1.5 & 1 & \\
\hline 13 & 0 & - & - & - & 5.8 & 5.8 & 1 & \\
\hline 14 & 1 & 2.6 & 2.6 & - & - & 2.6 & 0 & \\
\hline 15 & 0 & - & - & - & 12.1 & 12.1 & 1 & \\
\hline 16 & 0 & - & - & - & 7.3 & 7.3 & 0 & Collapsed \\
\hline 17 & 0 & - & - & - & 3.6 & 3.6 & 0 & \\
\hline 18 & 1 & 11.4 & 11.4 & - & - & 11.4 & 1 & \\
\hline 19 & 0 & - & - & - & 8.2 & 8.2 & 2 & \\
\hline 20 & 0 & - & - & - & 3.6 & 3.6 & 1 & \\
\hline
\end{tabular}

plus procyonids, a relationship advocated directly by only Braunitzer \& Hofmann (1987). In part, this unusual placement reflects the support for an Ailurus fulgens-procyonid clade (four source trees), but one that is outweighed by 10 source trees linking mustelids and procyonids with no statement regarding Ailurus fulgens. Interestingly, more source trees (11) advocate allying Ailurus fulgens with the ursids, but this solution is not globally most parsimonious. It should be noted that support for the placement of the red panda in the composite tree is exceptionally weak compared to the remaining nodes at this level (Table 2). The pinnipeds are held to be monophyletic in agreement with current opinion, but with an unusual sister group: the Musteloidea (plus Ailurus fulgens) in place of the more commonly suggested ursids. The composite tree also shows strong support for the traditional Otarioidea (odobenids plus otariids), in contrast to Wyss's (1987) recent assertion of an odobenid-phocid pairing.

Within mustelids (Fig. 2), the monophyly of the classic Simpsonian subfamilies (Lutrinae, Melinae, Mellivorinae, Mephitinae, Mustelinae; Simpson, 1945) are upheld with the possible exception of the badgers (Melinae) and ignoring the monotypic
Mellivorinae. Although no definite statement can be made regarding the cladistic status of the former subfamily, the position of the meline taxa at the base of the tree suggests that it might have been originally erected on the basis of shared primitive features (symplesiomorphies). In our analyses, the mephitines (skunks) were constrained to be mustelids; however, the large negative branch length around this region (Tables 3 and 5) suggests a more ancient origin of this group and may support the paraphyly of the Mustelidae (e.g. Arnason \& Widegren, 1986; Wayne et al., 1989 a; Arnason \& Ledje, 1993; Vrana et al., 1994; Ledje \& Arnason, 1996). Relationships within the mustelids are generally not strongly supported (Tables 3-5). All subgenera of Mustela (see Youngman, 1982; Nowak, 1991) are indicated to be monophyletic except the nominal subgenus (species altaica, erminea, frenata, kathiah and nivalis) (Fig. 2). Within otters (Fig. 3), Lutra is polyphyletic and there is much uncertainty regarding the relationships among the major lineages. Among mephitines (Fig. 4), the South American species of Conepatus (chinga, humboldtii and semistriatus) do not form a single clade.

The procyonids are divided into their two recognized subfamilies with all relationships receiving 
Table 13. Statistics relating to the times of divergence of and support for the nodes of the composite tree for Viverridae (see Fig. 12). Other details are as in Table 2

\begin{tabular}{|c|c|c|c|c|c|c|c|c|}
\hline \multirow[b]{2}{*}{ Node } & \multicolumn{4}{|c|}{ Literature estimates } & \multirow{2}{*}{$\begin{array}{l}\text { Birth } \\
\text { model }\end{array}$} & \multirow{2}{*}{$\begin{array}{l}\text { Best } \\
\text { estimate }\end{array}$} & \multirow{2}{*}{$\begin{array}{l}\text { Bremer } \\
\text { support }\end{array}$} & \multirow{2}{*}{$\begin{array}{l}\text { Differential } \\
\text { weighting }\end{array}$} \\
\hline & $\mathcal{N}$ & Median & Mean & S.E.M. & & & & \\
\hline 1 & 0 & - & - & - & 27.5 & 27.5 & $\mathrm{n} / \mathrm{a}$ & \\
\hline 2 & 1 & 27.2 & 27.2 & - & - & 27.2 & 5 & \\
\hline 3 & 3 & 27.2 & 26.4 & 3.2 & - & 27.2 & 6 & \\
\hline 4 & 0 & - & - & - & 14.5 & 14.5 & 1 & \\
\hline 5 & 0 & - & - & - & 14.0 & 14.0 & 1 & \\
\hline 6 & 3 & 4.5 & 7.4 & 3.5 & - & 4.5 & 4 & \\
\hline 7 & 0 & - & - & - & 4.0 & 4.0 & 1 & \\
\hline 8 & 0 & - & - & - & 3.3 & 3.3 & 1 & \\
\hline 9 & 0 & - & - & - & 2.2 & 2.2 & 1 & \\
\hline 10 & 0 & - & - & - & 1.4 & 1.4 & 2 & \\
\hline 11 & 0 & - & - & - & 1.4 & 1.4 & 1 & \\
\hline 12 & 1 & 2.6 & 2.6 & - & - & 2.6 & 1 & \\
\hline 13 & 0 & - & - & - & 1.4 & 1.4 & 2 & \\
\hline 14 & 0 & - & - & - & 10.2 & 10.2 & 2 & \\
\hline 15 & 0 & - & - & - & 6.4 & 6.4 & 3 & \\
\hline 16 & 1 & 2.6 & 2.6 & - & - & 10.3 & 1 & \\
\hline 17 & 2 & 15.2 & 15.2 & 1.4 & - & 10.3 & 1 & \\
\hline 18 & 0 & - & - & - & 13.0 & 10.3 & 2 & \\
\hline 19 & 0 & - & - & - & 6.5 & 6.5 & 2 & \\
\hline 20 & 0 & - & - & - & 6.5 & 6.5 & 1 & \\
\hline 21 & 0 & - & - & - & 27.2 & 27.2 & 3 & \\
\hline 22 & 0 & - & - & - & 22.7 & 22.7 & 1 & \\
\hline 23 & 0 & - & - & - & 21.3 & 21.3 & 3 & \\
\hline 24 & 0 & - & - & - & 19.6 & 21.0 & 1 & \\
\hline 25 & 1 & 22.4 & 22.4 & - & - & 21.0 & 1 & \\
\hline 26 & 0 & - & - & - & 15.3 & 15.3 & 3 & \\
\hline 27 & 0 & - & - & - & 9.7 & 9.7 & 1 & \\
\hline 28 & 0 & - & - & - & 9.7 & 9.7 & 1 & \\
\hline 29 & 0 & - & - & - & 11.0 & 11.0 & 6 & \\
\hline 30 & 0 & - & - & - & 8.7 & 8.7 & 1 & \\
\hline 31 & 0 & - & - & - & 8.4 & 8.4 & 2 & \\
\hline 32 & 0 & - & - & - & 5.3 & 5.3 & 4 & \\
\hline
\end{tabular}

intermediate support (Fig. 5; Table 6). The lack of resolution within Bassaricyon and Procyon reflects a complete lack of information as noted previously.

The composite tree bears on two issues within the pinnipeds. Within otariids (Fig. 6), there is much uncertainty concerning the fur seals (genera Arctocephalus and Callorhinus). Monophyly of this subfamily cannot be assured, supporting the view that subfamilial distinction within the otariids is unnecessary (Tedford, 1976; Repenning \& Tedford, 1977). Relationships within Arctocephalus are largely unresolved due to both a general lack of research effort and conflicting source trees, the latter possibly owing to the high degree of convergence among species (Berta \& Deméré, 1986). In contrast, the phocid tree (Fig. 7) is more resolved and addresses four hypotheses of paraphyly within the family. The genus Phoca is indicated to be paraphyletic [although its subgenera (see Burns \& Fay, 1970) are monophyletic] with respect to Halichoerus grypus, a point often raised in the literature (e.g. Chapskii, 1955; McLaren, 1975; de Muizon, 1982b; Wyss, 1988; Arnason et al., 1993, 1995; Mouchaty, Cook \& Shields, 1995; Perry et al., 1995). Other hypotheses of paraphyly within the phocids are not supported here: the subfamily Monachinae (Wyss, 1988), the tribe Lobodontini (Bininda-Emonds \& Russell, 1996), and the genus Monachus (Wyss, 1988) are all monophyletic in the composite tree. Finally, Arnason et al. (1996) have used the divergence of Phoca (but 
actually equivalent to node 5 on Fig. 7) as a standard reference for calibrating recent mammalian divergence events (the 'Phoca standard'); however, Table 8 indicates their estimate of 2.7 MYBP to be too recent.

The giant panda (Ailuropoda melanoleuca), which was constrained in our analyses to be an ursid (see 'Methodology'), is very clearly the sister group to the other bears in the composite tree (Fig. 8; Table 9). The position of the American black bear (Ursus americanus) remains contentious and merits further investigation; the polytomy in this region agrees with recent, independent molecular findings (L. Waits, personal communication). At present, the monophyly of Ursus is not assured, which supports continuing calls for a revision of the genus-level taxonomy of ursids (see Goldman, Giri \& O'Brien, 1989; Zhang \& Ryder, 1994). The close association between the brown and polar bears $(U$. arctos and $U$. maritimus, respectively) is upheld, reflecting suggestions that the two might be conspecific (e.g. Cronin et al., 1991; Talbot \& Shields, 1996). The elevation of the polar bear to its own genus (Thalarctos; Corbet \& Hill, 1991) is clearly not appropriate without additional taxonomic alterations.

Canids are divided into two main clades (Fig. 9), corresponding roughly to the 'dog-like' and 'foxlike' forms of many authors (= Canini and Vulpini, respectively, of Tedford, Taylor \& Wang, 1995). The problematic genera Nyctereutes and Otocyon cluster with the dog-like and fox-like clades, respectively, although Nyctereutes could almost equally well be placed with Otocyon (results not shown). Of the monotypic dog-like genera, only the Falkland Island wolf (Dusicyon australis) is placed unambiguously, forming the sister group to the South American 'foxes' (Pseudalopex spp.), which have frequently been considered to belong in the same genus as it. Canis forms a well-defined clade divided into 'wolf-like' and 'jackal-like' forms. The Simien jackal (C. simensis) clearly clusters with the wolf-like forms and so justifies its less frequently used common name of the Ethiopian wolf (see Gottelli et al., 1994; Geffen et al., 1996). The red wolf (C.rufus) forms the sister taxon to the grey wolf (C. lupus), although the support for this placement is overestimated in Table 10. Several authors (e.g. Wayne \& Jenks, 1991; Roy et al., 1994; possibly Lawrence \& Bossert, 1967) hold C. rufus to be a hybrid between the coyote and the grey wolf, which we coded as a polytomy between the three species. However, in our analyses, a polytomy is always outweighed by any fully resolved answer. Two studies advocated a hybrid origin while four clustered $C$. rufus with $C$. lupus as on the composite tree. With the exception of the South American 'foxes', the fox-like canids form a distinct cluster with Otocyon and Urocyon in basal positions. Vulpes is indicated to be paraphyletic with respect to the Arctic fox (Alopex lagopus), an outcome supporting those arguing against the generic distinction of the latter (e.g. Tedford et al., 1995).

The composite tree for felids is largely resolved (Fig. 10), but the backbone is weakly supported (Table 11), reflecting the historical controversy over felid phylogeny. Three of the better supported clades (nodes 7, 19 and 26) correspond to major clades in recent molecular phylogenies from S. J. O'Brien's research group: the Panthera group, the ocelot lineage, and the domestic cat lineage, respectively (see O'Brien et al., 1996). Most of the extant species within the ocelot lineage radiated between 3.7 and 3.0 MYBP (Table 11). Although this time scale accords with some estimates of the earliest formation of the Panamanian land bridge (e.g. White, 1986; Martin, 1989), it predates others (e.g. Stehli \& Webb, 1985; Wayne et al., 1991) as well as the first appearance of fossil felids in South America (1.9-2.4 MYBP; Hunt, 1996) and the time of the greatest faunal exchange between North and South America (Plio-Pleistocene; Hunt, 1996). If our dates are accurate, they suggest that much of the diversification within the ocelot lineage may have occurred before it reached South America (contra Pecon Slattery et al., 1994) or shortly thereafter. The pantherine lineage of O'Brien et al. (1996) is not monophyletic in our tree, being split into a major terminal clade (node 6) and numerous smaller lineages in the basal portion of the composite tree. The cheetah (Acinonyx jubatus) occupies its traditional position as sister taxon to the remaining felids (Král \& Zima, 1980; Martin, 1980) rather than to Puma (contra O'Brien et al., 1996). Within the terminal clade, the golden cats (Catopuma temminckii and Profelis aurata) are paraphyletic with respect to the bay cat (Catopuma badia), rather than polyphyletic as found by O'Brien et al. (1996). Despite the lack of robustness of many nodes, all but two of the genera recognized by Wozencraft (1993), Leopardus and Oncifelis, are monophyletic. Altogether, the pattern we found of well-supported groups of uncertain interrelationships (i.e. the weak backbone) reflects current opinion of felid phylogeny (S. J. O'Brien, personal communication).

In hyaenids (Fig. 1), the only point of consensus is the sister group status of the aardwolf (Proteles cristatus) to the remaining species. The traditional 
view that Crocuta crocuta was the sister group to the previously congeneric Hyaena hyaena and Parahyaena brunnea has fallen out of favour recently (see Werdelin \& Solounias, 1991), but no dominant opinion has replaced it: all three possible resolutions of the polytomy were represented at least once among the five relevant source trees.

The initial analysis of all herpestid species supported only the monophyly of the two subfamilies and the genera within them (Fig. 11 A). However, removing the poorly known species from the analysis (see 'Methodology') revealed a surprising amount of structure within herpestines, although resolution within genera is still poor (Fig. $11 \mathrm{~B}$ ). The positions of two genera, Dologale and Rhynchogale, within herpestines are completely unknown and their positions in Fig. $11 \mathrm{~B}$ should be treated as highly suspect. This family in general and the poorly known species in particular (whose indicated positions are more statements of membership than hypotheses of relationship) need further systematic research.

Viverrids (Fig. 12) cluster into their commonly recognized subfamilies (see Wozencraft, 1993). Nandinia binotata forms the sister group to the paradoxurines in our analysis, but our assumption of viverrid monophyly precluded a test of the suggestion that it may be a primitive feliform (Hunt, 1974; Wiig, 1985; Flynn et al., 1988; Hunt \& Tedford, 1993; Flynn, 1996; but see Radinsky, 1975). Evidence for the latter placement relies largely on the morphology of the auditory bulla. An equal number of studies based on a wider selection of data place Nandinia binotata within viverrids (e.g. Gregory \& Hellman, 1939; Petter, 1974; Stains, 1983; Wozencraft, 1984; Taylor, 1988); however, these studies may not have directly tested this question. Removal of the unusually comprehensive (and possibly dominating) study of Wozencraft (1984) did not alter the basic topology, but decreases resolution within the paradoxurines and Genetta (results not shown). Table 13 shows that three viverrid lineages are long-lived, diversifying before those in other families, if not before the diversification of (the extant members of) the families themselves.

In summary, instances of non-monophyly were rare, occurring only for the genera Lutra (lutrines), Phoca (phocids), Vulpes (canids), Leopardus (felids), Oncifelis (felids), and possibly Ursus (ursids); the nominal subgenus of Mustela (mustelids); and some other felid groups. This low level of non-monophyly reflects both tacit assumptions of monophyly of higher level taxa (see 'Methodology'), but probably also the general consensus over current carnivoran taxonomy.

\section{(6) Macroevolutionary trends}

To illustrate the utility of our complete phylogeny for studies of macroevolution, we have used it to pinpoint evolutionary radiations; that is, lineages containing significantly more species than expected for their age. The null expectation comes from a model in which all contemporaneous lineages have the same propensity to diversify (Nee et al., 1995). We do not assume any particular model of cladogenesis such as a constant-rates birth-death model. The test, implemented in End-Epi (Rambaut, Harvey \& Nee, 1997), identifies ancestral lineages that have given rise to 'more than their fair share' of extant species in comparison with their contemporaries (see Purvis, Nee \& Harvey, 1995 for a more detailed description).

The results are shown in Fig. 13. Eight lineages contain significantly more species than expected $(P<0.05)$, with six of them significant at the $P=0.01$ level. Note that radiations are not independent: if a lineage is a radiation, more inclusive clades will also tend to be. Interpreting Fig. 13 must therefore be tentative, but there is at least one radiation within each of Mustelinae and Canidae. The genus Procyon (node 4 in Fig. 5) also appears to be a radiation, but its date of divergence is based upon a single estimate and so may be inaccurate. No radiations are apparent within Feliformia when the order is analysed as a whole. However, if Caniformia (including pinnipeds) and Feliformia are analysed separately, four feliform radiations are significant at the $P=0.01$ level. These are Felidae (Fig. 10), Genetta (node 6 in Fig. 12), node 6 within Felidae (Fig. 10) and node 8 within Herpestidae (Fig. 11 B); the latter two, however, are dated from single estimates. No new radiations appear when Caniformia is analysed on its own. Our results tentatively corroborate the suggestion that extant fields are an adaptive radiation (e.g. O'Brien et al., 1996), but do not support similar inferences for the phocine seals (e.g. Ray, 1976; Mouchaty et al., 1995) or ursine bears (e.g. O'Brien et al., 1985; Goldman et al., 1989). As more radiations are identified from further large phylogenies, it will become possible to test for general correlates of extreme diversification (Purvis, 1996).

Interestingly, our results suggest that the distribution of species among lineages is much more even in Carnivora than in Primates, where the 
Cercopithecidae (Old World monkeys) constitute a massive radiation (Purvis et al., 1995). There is also a marked difference in the distribution of speciespoor lineages. According to Tables 2-13, 19 carnivore species last shared a common ancestor with any other extant species more than 15 MYBP. By comparison, only three primate species are so isolated (Purvis, 1995a). Even allowing for uncertainties in the dates, these differences between carnivores and primates clearly merit further investigation.

\section{GONGLUSIONS}

(1) Supertree construction is a powerful new tool for building larger and more comprehensive phylogenies. MRP in particular combines positive aspects of both character and taxonomic congruence approaches.

(2) By using MRP, we have constructed the first full species-level phylogeny for all extant species of Carnivora from a wide variety of data sources spanning 25 years of systematic research into this mammalian order. The incompatibility and potential heterogeneity in signal among some of these data sets would preclude obtaining an answer using character congruence, and taxonomic congruence's reliance on consensus techniques would result in a much less resolved answer.

(3) Our composite tree shows that disparate studies of carnivoran phylogeny agree to a surprising extent: poorly resolved taxa are generally those that have been studied least. More research is clearly merited for herpestids and viverrids as a whole and within the procyonid genera Bassaricyon and Procyon. For some other questions (e.g. relationships among felid genera and among hyaenines, and the positions of the red panda and of the monotypic 'dog-like' canid genera), no clear answers have emerged despite considerable effort. Additional data may help resolve these issues; however, it may be that they are inherently difficult because they involve successive splitting events that were close together in time, and long ago.

(4) The tree we present is the largest complete species-level phylogeny for any group. It will provide a touchstone for many kinds of comparative study within carnivores (e.g. character evolution, macroevolutionary studies, conservation studies) and has already been used to test for correlations between population size and geographic range in British mammals (Blackburn et al., 1997), between body size and species richness in all carnivores (Gittleman \& Purvis, 1998), between foraging strategy and the extent of stereotypic behaviour displayed by captive carnivores (Clubb \& Mason, 1998), and to examine for edge effects with respect to the conservation biology of large carnivores (Woodroffe \& Ginsberg, 1998). Our tree also serves as a strawman for further systematic research into this fascinating order.

\section{AGKNOWLEDGEMENTS}

We thank Paul Harvey, Steve O'Brien, David Penny and especially Harold Bryant for helpful discussion, comments, and ideas. Additional constructive comments were provided by several anonymous referees and Phyllis Lee. Greg Anderson, David Bininda and Kevin Seymour helped to track down some of the more obscure or elusive references. Financial support was provided by Alberta Heritage, the United Kingdom's Overseas Research Scholarship plan, and an NSERC postgraduate scholarship (O.R.P.B.-E.); a Professional Leave Award from the Graduate School of the University of Tennessee, the Department of Zoology of the University of Oxford, and the NERC Centre for Population Biology at Silwood Park, Imperial College (J.L.G.); and the Royal Society, the NERG (GR3/8515) and the Department of Ecology and Evolutionary Biology at the University of Tennessee (A.P.).

\section{REFERENGES}

(References marked with * and/or $\uparrow$ were used, respectively, as sources of phylogenies or date estimates for the composite phylogeny.)

Adams, E. M. III. (1972). Consensus techniques and the comparison of taxonomic trees. Systematic Zoology 21, 390-397.

*Ahmed, A., Jahan, M. \& Braunitzer, G. (1990). Carnivora: the primary structure of hemoglobin from adult coati (Nasua nasua rufa, Procyonidae). Fournal of Protein Chemistry 9, 23-29.

* Ahmed, A., Jahan, M. \& Braunitzer, G. (1992). Carnivora: the primary structure of the major haemoglobin component from adult European lynx (Lynx lynx, Felidae). Fournal of Protein Chemistry 11, 39-43.

*Anbinder, E. M. (1971). Chromosomal sets of the Greenland, Caspian and Baikal seals and some problems of the evolution of true seals (Phocidae). Tsitologiya 13, 341-347.

$* \uparrow$ Anderson, E. (1970). Quaternary evolution of the Genus Martes (Carnivora, Mustelidae). Acta Zoologica Fennica 130, $1-132$.

* † Anderson, E. (1989). The phylogeny of mustelids and the systematics of ferrets. In Conservation Biology and the Black-footed Ferret (ed. U. S. Seal, E. T. Thorne, M. A. Bogan and S. H. Anderson), pp. 10-20. Yale University Press, New Haven, Connecticut.

$\dagger$ Anderson, E., Forrest, S. C., Clark, T. W. \& Richardson, L. (1986). Paleobiology, biogeography, and systematics of the black-footed ferret, Mustela nigripes (Audubon and Bachman), 1851. Great Basin Naturalist Memoirs 8, 11-62. 
*Arnason, U. (1977). The relationship between the four principal pinniped karyotypes. Hereditas 87, 227-242.

*†Arnason, U., Bodin, K., Gullberg, A., Ledje, C. \& Mouchaty, S. (1995). A molecular view of pinniped relationships with particular emphasis on the true seals. Fournal of Molecular Evolution 40, 78-85.

†Arnason, U., Gullberg, A., Johnsson, E. \& Ledje, C. (1993). The nucleotide sequence of the mitochondrial DNA molecule of the grey seal, Halichoerus grypus, and a comparison with mitochondrial sequences of other true seals. Fournal of Molecular Evolution 37, 323-330.

*Arnason, U. \& Ledje, C. (1993). The use of highly repetitive DNA for resolving cetacean and pinniped phylogenies. In Mammalian Phylogeny: Placentals, vol. 3 (ed. F. S. Szalay, M. J. Novacek and M. C. McKenna), pp. 74-80. Springer-Verlag, New York.

*Arnason, U. \& Widegren, B. (1986). Pinniped phylogeny enlightened by molecular hybridizations using highly repetitive DNA. Molecular Biology and Evolution 3, 356-365.

Arnason, U., Xu, X., Gullberg, A. \& Graur, D. (1996). The 'Phoca standard': an external molecular reference for calibrating recent evolutionary divergences. Fournal of Molecular Evolution 43, 41-45.

*Atkins, D. L. (1978). Evolution and morphology of the coyote brain. In Coyotes: Biology, Behavior, and Management (ed. M. Bekoff), pp. 17-35. Academic Press, New York.

*Atkins, D. L. \& Dillon, L. S. (1971). Evolution of the cerebellum in the genus Canis. Fournal of Mammalogy 52, 96-107.

*Austin, P. K. (1996). Systematic relationships of the Herpestidae (Mammalia: Carnivora). M.Sc. thesis, University of Illinois, Chicago.

Bailey, W. J., Fitch, D. H. A., Tagle, D. A., Czelusniak, J., Slightom, J. A. \& Goodman, M. (1991). Molecular evolution of the $\eta$-globin gene locus: gibbon phylogeny and the hominoid slowdown. Molecular Biology and Evolution 8, 155-184.

*†Barnes, L. G., Domning, D. P. \& Ray, C. E. (1985). Status of studies on fossil marine mammals. Marine Mammal Science $\mathbf{1}$, 15-53.

Barrett, M., Donoghue, M. J. \& Sober, E. (1991). Against consensus. Systematic Zoology 40, 486-493.

$* \dagger$ Baskin, J. A. (1982). Tertiary Procyonidae (Mammalia: Carnivora) of North America. Fournal of Vertebrate Paleontology 2, 71-93.

Baskin, J. A. (1989). Comments on New World Tertiary Procyonidae (Mammalia: Carnivora). Journal of Vertebrate Paleontology 9, 110-117.

Baum, B. R. (1992). Combining trees as a way of combining data sets for phylogenetic inference, and the desirability of combining gene trees. Taxon 41, 3-10.

Baum, B. R. \& Ragan, M. A. (1993). Reply to A. G. Rodrigo's 'A comment on Baum's method for combining phylogenetic trees'. Taxon 42, 637-640.

*Beentjes, M. P. (1990). Comparative terrestrial locomotion of the Hooker's sea lion (Phocarctos hookeri) and the New Zealand fur seal (Arctocephalus forsteri): evolutionary and ecological implications. Zoological Fournal of the Linnean Society 98, 307-325.

*Belyaev, D. K., Baranov, O. K., Fomicheva, I. I., Smirnych, S. I., Ternovsky, D. V. \& Ternovskaya, J. G. (1984). Interspecific antigenic variation of serum proteins in the family Mustelidae (Carnivora). Zoologicheskii Zhurnal 63, 912-922.
* $†$ Benveniste, R. E. (1985). The contributions of retroviruses to the study of mammalian evolution. In Molecular Evolutionary Genetics (ed. R. J. MacIntyre), pp. 359-417. Plenum Press, New York.

* $†$ Berta, A. (1987). Origin, diversification, and zoogeography of the South American Canidae. Fieldiana Zoology 39, 455-471.

Berta, A. (1991). New Enaliarctos* (Pinnipedimorpha) from the Oligocene and Miocene of Oregon and the role of 'enaliarctids' in pinniped phylogeny. Smithsonian Contributions to Paleobiology 69, 1-33.

*Berta, A. \& Deméré, T. (1986). Callorhinus gilmorei n. sp. (Carnivora: Otariidae) from the San Diego Formation (Blancan) and its implications for otariid phylogeny. Transactions of the San Diego Society of Natural History 21, 111-126.

*Berta, A. \& Wyss, A. R. (1994). Pinniped phylogeny. In Contributions in Marine Mammal Paleontology Honoring Frank C. Whitmore, Fr., vol. 29 (ed. A. Berta and T. A. Deméré), pp. 33-56. Proceedings of the San Diego Society of Natural History, San Diego.

Bininda-Emonds, O. R. P. \& Bryant, H. N. (1998). Properties of matrix representation with parsimony analyses. Systematic Biology 47, 497-508.

*Bininda-Emonds, O. R. P. \& Russell, A. P. (1996). A morphological perspective on the phylogenetic relationships of the extant phocid seals (Mammalia: Carnivora: Phocidae). Bonner zoologische Monographien 41, 1-256.

Blackburn, T. M., Gaston, K. J., Quinn, R. M., Arnold, H. \& Gregory, R. D. (1997). Of mice and wrens: the relation between abundance and geographic range size in British mammals and birds. Philosophical Transactions of the Royal Society of London B 352, 419-427.

* $†$ Bogdanov, L. V. \& Pastukhov, V. D. (1982). [New data on the taxonomic position of the Baikal seal Phoca (Pusa) sibirica Gmel.]. In [Morpho-Physiological and Ecological Studies of the Baikal Seal] (ed. V. D. Pastukhov), pp. 7-12. Nauka, Novosibirsk.

*Braunitzer, G. \& Hofmann, O. (1987). Les hémoglobins des pandas. Comptes Rendus des Séances de la Société de Biologie et de ses Filiales 181, 116-121.

Bremer, K. (1988). The limits of amino acid sequence data in angiosperm phylogenetic reconstruction. Evolution 42, 795-803.

*†Bryant, H. N., Russell, A. P. \& Fitch, W. D. (1993). Phylogenetic relationships within the extant Mustelidae (Carnivora): appraisal of the cladistic status of the Simpsonian subfamilies. Zoological Journal of the Linnean Society 108, 301-334.

*Bugge, J. (1978). The cephalic arterial system in carnivores, with special reference to the systematic classification. Acta Anatomica 101, 45-61.

Bull, J. J., Huelsenbegk, J. P., Gunningham, G. W., Swofford, D. L. \& Waddell, P. J. (1993). Partitioning and combining data in phylogenetic analysis. Systematic Biology 42, 384-397.

*Burns, J. J. \& Fay, F. H. (1970). Comparative morphology of the skull of the Ribbon seal, Histriophoca fasciata, with remarks on the systematics of Phocidae. Fournal of Zoology 161, 363-394.

$†$ Centerwall, W. R., Wurster-Hill, D. H. \& Benveniste, R. E. (1985). Cytogenetic evolution of the world's felines. Clinical Research 33, A117.

*Chapskir, K. K. (1955). An attempt at revision of the systematics and diagnostics of seals of the subfamily Phocinae. Trudy Zoologicheskovo Instituta Akademii Nauk SSSR 17, 160-199. 
[In Russian. English translation by Jeletzky, T. F. 1957. Fisheries Research Board of Canada Translation Series 114.]

* Chiarelli, A. B. (1975). The chromosomes of the Canidae. In The Wild Canids : their Systematics, Behavioral Ecology and Evolution (ed. M. W. Fox), pp. 40-53. Van Nostrand Reinhold Company, New York.

Chippindale, P. T. \& Wiens, J. J. (1994). Weighting, partitioning, and combining characters in phylogenetic analysis. Systematic Biology 43, 278-287.

Clubb, R. \& Mason, G. (1998). Foraging niche and stereotypic behaviour. In Proceedings of the 32nd Congress of the International Society for Applied Ethology, 21-25 fuly 1998, Clermont-Ferrand, France (ed. I. Veissier and A. Boissy), pp. 174. Institut National de la Recherché Agronomique, France.

*Clutton-Brock, J., Corbet, G. B. \& Hills, M. (1976). A review of the family Canidae, with a classification by numerical methods. Bulletin of the British Museum of Natural History 29, 120-199.

* † Collier, G. E. \& O'Brien, S. J. (1985). A molecular phylogeny of the Felidae: immunological distance. Evolution 39, 473-487.

Corbet, G. B. \& Hill, J. E. (1991). A World List of Mammalian Species. Oxford University Press, Oxford.

*Couturier, J. \& Dutrillaux, B. (1985). Evolution chromosomique chez les Carnivores. Mammalia 50A, 124-162.

Cozzuol, M. A. (1992). The oldest seal of the southern hemisphere: implications to phocid phylogeny and dispersal. Fournal of Vertebrate Paleontology 12, 25A-26A.

*Crawford-Cabral, J. (1982 (intended 1980-1981)). The classification of the genets (Carnivora, Viverridae, genus Genetta). Boletim da Sociedade Portuguesa de Ciencias Naturais 20, 97-114.

Creel, S. \& Macdonald, D. (1995). Sociality, group size, and reproductive suppression in carnivores. Advances in the Study of Behavior 24, 203-257.

*†Cronin, M. A., Amstrup, S. C., Garner, G. W. \& Vyse, E. R. (1991). Interspecific and intraspecific mitochondrial DNA variation in North American bears (Ursus). Canadian Fournal of Zoology 69, 2985-2992.

*Czelusniak, J., Goodman, M., Koop, B. F., Tagle, D. A., Shoshani, J., Braunitzer, G., Kleinschmidt, T. K., de Jong, W. W. \& Matsuda, G. (1991). Perspectives from amino acid and nucleotide sequences on cladistic relationships among higher taxa of eutheria. In Current Mammalogy, vol. 2 (ed. H. H. Genoways), pp. 545-572. Plenum Press, New York.

*Czelusniak, J., Goodman, M., Moncrief, N. D. \& Kehoe, S. M. (1990). Maximum parsimony approach to construction of evolutionary trees from aligned homologous sequences. Methods in Enzymology 183, 601-615.

*Darbre, P. D. \& Lehmann, H. (1976). Comparison of the myoglobin of the bat-eared fox (Otocyon megalotis) with that of the domestic dog (Canis familiaris). Biochimica et Biophysica Acta 453, 285-288.

*Davis, J. A. (1978). A classification of the otters. In Otters Proceedings of the first working meeting of the otter specialist group of the survival service commission (ed. N. Duplaix), pp. 14-33. IUCN (International Union for Conservation of Nature and Natural Resources) Publication. New Series.

* De Jong, W. W. (1986). Protein sequence evidence for monophyly of the carnivore families Procyonidae and Mustelidae. Molecular Biology And Evolution 3, 276-281.

*de Muizon, C. $(1982 a)$. Les relations phylogénétiques des
Lutrinae (Mustelidae, Mammalia). Geobios Mémoires Spécial 6, 259-277.

*de Muizon, C. $(1982 b)$. Phocid phylogeny and dispersal. Annals of the South African Museum 89, 175-213.

de Queiroz, A., Donoghue, M. J. \& Kim, J. (1995). Separate versus combined analysis of phylogenetic evidence. Annual Review of Ecology and Systematics 26, 657-681.

*Degker, D. M. (1996). The utility of chemical signals as characters in phylogenetic studies: examples from the Felidae. Ph.D. thesis, University of Knoxville, Tennessee.

*Decker, D. M. \& Wozencraft, W. C. (1991). Phylogenetic analysis of Recent procyonid genera. Journal of Mammalogy 72, $42-55$.

Donoghue, M. J., Doyle, J. A., Gauthier, J., Kluge, A. G. \& Rowe, T. (1989). The importance of fossils in phylogeny reconstruction. Annual Review of Ecology and Systematics 20, 431-460.

*†Dragoo, J. W., Bradley, R. D., Honeycutt, R. L. \& Templeton, J. W. (1993). Phylogenetic relationships among the skunks: a molecular perspective. Journal of Mammalian Evolution 1, 255-267.

*Dutrillaux, B., Couturier, J. \& Chauvier, G. (1982). Notes et discussions sur 'Édentes', Carnivores, 'Pinnipèdes' et leurs parasites. 3. - Les Pinnipèdes, monophylétiques, sont issus de Procyonidae ancestraux, et non d'Ursidae ni de Mustelidae. Mémoires du Muséum National d'Histoire Naturelle Série A Zoologie 123, 141-143.

*†Essop, M. F., Emmanuel, M. \& Harley, E. H. (1988). Mitochondrial DNA analyses for the molecular taxonomy of South African mammals. Transactions of the Royal Society of South Africa 46, 291-293.

FARRIs, J. S. (1983). The logical basis of phylogenetic analysis. In Advances in Cladistics, vol. 2 (ed. N. I. Platnick and V. A. Funk), pp. 7-36. Columbia University Press, New York.

Farris, J. S., Albert, V. A., Källersjö, M., Lipscomb, D. \& Kluge, A. G. (1996). Parsimony jackknifing outperforms neighbor-joining. Cladistics 12, 99-124.

Felsenstein, J. (1985a). Confidence limits on phylogenies: an approach using the bootstrap. Evolution 39, 783-791.

Felsenstein, J. (1985b). Phylogenies and the comparative method. American Naturalist 125, 1-15.

*†Figcarelli, G. (1979). Osservazione sull'evoluzione del genere Ursus. Bollettino della Società Paleontologica Italiana 18, $166-172$.

Flynn, J.J. (1988). Ancestry of sea mammals. Nature 334, 383-384.

Flynn, J.J. (1996). Carnivoran phylogeny and rates of evolution: morphological, taxic, and molecular. In Carnivore Behavior, Ecology, and Evolution, vol. 2 (ed. J. L. Gittleman), pp. 542-581. Cornell University Press, Ithaca, New York.

*Flynn, J. J. \& Galiano, H. (1982). Phylogeny of the early Tertiary Carnivora, with a description of a new species of Protictis from the middle Eocene of northwestern Wyoming. American Museum Novitates 2725, 1-64.

*Flynn, J. J., Neff, N. A. \& Tedford, R. H. (1988). Phylogeny of the Carnivora. In The Phylogeny and Classification of the Tetrapods, vol. 2 - Mammals (ed. M. J. Benton), pp. 73-116. Clarendon Press, Oxford.

*Fox, M. W. (1971). The Behavior of Wolves, Dogs and Related Canids. Harper and Row, New York.

*Fredga, K. (1972). Comparative chromosome studies in mongooses (Carnivora, Viverridae). Hereditas 71, 1-74.

*Galiano, H. \& Frailey, D. (1977). Chasmaporthetes kani, new 
species from China, with remarks on phylogenetic relationships of genera within the Hyaenidae (Mammalia, Carnivora). American Museum Novitates 2632, 1-16.

* †Garland, T. Jr., Dickerman, A. W., Janis, C. M. \& Jones, J. A. (1993). Phylogenetic analysis of covariance by computer simulation. Systematic Biology 42, 265-292.

Gauthier, J., Kluge, A. G. \& Rowe, T. (1988). Amniote phylogeny and the importance of fossils. Cladistics 4, 105-209.

*†Geffen, E., Gompper, M. E., Gittleman, J. L., Luh, H.-W., Magdonald, D. W. \& Wayne, R. K. (1996). Size, lifehistory traits, and social organization in the Canidae: a reevaluation. American Naturalist 147, 140-160.

*†Geffenn, E., Mercure, A., Girman, D. J., Macdonald, D. W. \& Wayne, R. K. (1992). Phylogenetic relationships of the fox-like canids: mitochondrial DNA restriction fragment, site and cytochrome $b$ sequence analyses. Fournal of Zoology 228, 27-39.

Gillespie, J. (1991). The Causes of Molecular Evolution. Oxford University Press, Oxford.

* Ginsburg, L. (1982). Sur la position systématique du petit panda, Ailurus fulgens (Carnivora, Mammalia). Géobios Mémoires Spécial 6, 247-258.

*Girman, D. J., Kat, P. W., Mills, M. G. L., Ginsberg, J. R., Borner, M., Wilson, V., Fanshawe, J. H., Fitzgibbon, C., Lau, L. M. \& Wayne, R. K. (1993). Molecular genetic and morphological analyses of the African wild dog (Lycaon pictus). Fournal of Heredity 84, 450-459.

†Gittleman, J. L. (1986). Carnivore brain size, behavioral ecology, and phylogeny. Fournal of Mammalogy 67, 23-36.

Gittleman, J. L. (ed.) (1989). Carnivore Behavior, Ecology, and Evolution. Cornell University Press, Ithaca, New York.

Gittleman, J. L. (1994a). Are the pandas successful specialists or evolutionary failures? BioScience 44, 456-464.

Gittleman, J. L. (1994b). Female brain size and parental care in carnivores. Proceedings of the National Academy of Sciences of the United States of America 91, 5495-5497.

Gittleman, J. L. (ed.) (1996). Carnivore Behavior, Ecology, and Evolution, vol. 2. Cornell University Press, Ithaca, New York.

Gittleman, J. L., Anderson, C. G., Kot, M. \& Luh, H.-K. (1996). Comparative tests of evolutionary lability and rates using molecular phylogenies. In New Uses for New Phylogenies (ed. P. H. Harvey, A. J. Leigh Brown, J. Maynard Smith and S. Nee), pp. 289-307. Oxford University Press, Oxford.

Gittleman, J. L. \& Purvis, A. (1998). Body size and speciesrichness in carnivores and primates. Proceedings of the Royal Society of London B 265, 113-119.

Gittleman, J. L. \& Van Valkenburgh, B. (1997). Sexual dimorphism in the canines and skulls of carnivores: the effects of size, phylogeny, and behavioural ecology. Fournal of Zoology 242, 97-117.

*Glass, G. E. \& Martin, L. D. (1978). A multivariate comparison of some extant and fossil Felidae. Carnivore 1, 80-87.

* †Goldman, D., Giri, P. R. \& O’Brien, S. J. (1989). Molecular genetic-distance estimates among the Ursidae as indicated by one- and two-dimensional protein electrophoresis. Evolution 43, 282-295.

*†Goodman, M., Romero-Herrera, A. E., Dene, H., Czzelusniak, J. \& Tashian, R. E. (1982). Amino acid sequence evidence on the phylogeny of primates and other eutherians. In Macromolecular Sequences in Systematics and Evolutionary Biology (ed. M. Goodman), pp. 115-191. Plenum Press, New York.
* †Gottelli, D., Sillero-Zubiri, C., Applebaum, G. D., Roy, M. S., Girman, D. J., Garcia-Moreno, J., Ostranders, E. A. \& Wayne, R. K. (1994). Molecular genetics of the most endangered canid: the Ethiopian wolf Canis simensis. Molecular Ecology 3, 301-312.

Graham, R. L. \& Foulds, L. R. (1982). Unlikelihood that minimal phylogenies for a realistic biological study can be constructed in reasonable computational time. Mathematical Biosciences 60, 133-142.

*Graphodatsky, A. S., Sharshov, A. A., Ternovsky, D. V. \& Ternovskaya, Y. G. (1989). Comparative cytogenesis of Mustelidae (Carnivora). Zoologicheskii Zhurnal 68, 96-106.

*Graphodatsky, A. S., Volobuev, V. T., Ternovsky, D. V. \& Radjabli, S. I. (1976). G-banding of the chromosomes in seven species of Mustelidae (Carnivora). Zoologischeskii Zhurnal 55, 1704-1709.

Graur, D. (1993). Molecular phylogeny and the higher classification of eutherian mammals. Trends in Ecology and Evolution 8, 141-147.

*Gregory, W. K. \& Hellman, M. (1939). On the evolution and major classification of the civets (Viverridae) and allied fossil and recent Carnivora: a phylogenetic study of the skull and dentition. Proceedings of the American Philosophical Society 81, 309-392.

*Grove, C. (1982). Cranial and dental characteristics in the systematics of Old World Felidae. Carnivore 5, 28-39.

Hall, E. R. (1981). The Mammals of North America. John Wiley \& Sons, New York.

*†Hartl, G. B., Willing, R., Grillitsch, M. \& Klansek, E. (1988). Biochemical variation in Mustelidae: are carnivores genetically less variable than other mammals. Zoologischer Anzeiger 221, 81-90.

Harvey, P. H., Leigh Brown, A. J., Maynard Smith, J. \& Nee, S. (ed.) (1996). New Uses for New Phylogenies. Oxford University Press, Oxford.

Harvey, P. H. \& Pagel, M. D. (1991). The Comparative Method in Evolutionary Biology. Oxford University Press, Oxford.

* † Hashimoto, T., Otaka, E., Adachi, J., Mizuta, K. \& Hasegawa, M. (1993). The giant panda is closer to a bear, judged by $\alpha$ - and $\beta$-hemoglobin sequences. Fournal of Molecular Evolution 36, 282-289.

*Hemmer, H. (1978). The evolutionary systematics of the living Felidae: present status and current problems. Carnivore 1, 71-79.

*Hemmer, H. (1981). Die Evolution der Pantherkatzen. Modell zur Überprüfung der Brauchbarkeit der HENNIGschen Prinzipien der phylogenetischen Systematik für wirbeltierpaläontologische Studien. Paläontologische Zeitschrift 55, 109-116.

* Hendey, Q. B. (1972). The evolution and dispersal of the Monachinae (Mammalia: Pinnipedia). Annals of the South African Museum 59, 99-113.

*Hendey, Q. B. (1978). Late Tertiary Hyaenidae from Langebaanweg, South Africa, and their relevance to the phylogeny of the family. Annals of the South African Museum 76, 265-297.

*Herrington, S.J. (1983). Systematics of the Felidae: a quantitative analysis. M.Sc. thesis, University of Oklahoma, Norman.

*Herrington, S. J. (1986). Phylogenetic relationships of the wild cats of the world. Ph.D. thesis, University of Kansas, Lawrence.

Hillis, D. M. \& Huelsenbeak, J. P. (1992). Signal, noise, and 
reliability in molecular phylogenetic analyses. Fournal of Heredity 83, 189-195.

*Hirota, K. S. B. (1994). Approaches to reconstruct Japanese sea lions (5). Phylogeny of the Otariidae. 2: Zalophus fossils from Japan and their phylogenetic problems. Aquabiology 16, 49-53.

$\dagger$ Hoberg, E. P. \& Adams, A. M. (1992). Phylogeny, historical biogeography, and ecology of Anophryocephalus spp. (Eucestoda: Tetrabothriidae) among pinnipeds of the Holarctic during the late Tertiary and Pleistocene. Canadian Fournal of Zoology 70, 703-719.

*†Hofmann, O. \& Braunitzer, G. (1987). The primary structure of the hemoglobin of spectacled bear (Tremarctos ornatus, Carnivora). Biological Chemistry Hoppe-Seyler 368, 949-954.

*Holmes, T. JR. (1988). Sexual dimorphism in North American weasels with a phylogeny of the Mustelidae. Ph.D. thesis, University of Kansas, Lawrence.

* † Hosoda, T., Suzuki, H., Yamada, T. \& Tsuchiya, K. (1993). Restriction site polymorphism in the ribosomal DNA of eight species of Canidae and Mustelidae. Cytologia 58, 223-230.

*Howell, F. C. \& Petter, G. (1980). The Pachycrocuta and Hyaena lineages (Plio-Pleistocene and extant species of the Hyaenidae). Their relationships with Miocene ictitheres: Palhyaena and Hyaenictitherium. Géobios 13, 579-623.

Huelsenbeck, J. P., Bull, J. J. \& Cunningham, C. W. (1996). Combining data in phylogenetic analysis. Trends in Ecology and Evolution 11, 152-158.

Humphries, C. J., Williams, P. H. \& Vane-Wright, R. I. (1995). Measuring biodiversity value for conservation. Annual Review of Ecology and Systematics 26, 93-111.

*Hunt, R. M. JR. (1974). The auditory bulla in Carnivora: an anatomical basis for reapparaisal of carnivore evolution. Journal of Morphology 143, 21-76.

$\dagger$ Hunt, R. M. JR. (1996). Biogeography of the order Carnivora. In Carnivore Behavior, Ecology, and Evolution, vol. 2 (ed. J. L. Gittleman), pp. 485-541. Cornell University Press, Ithaca, New York.

*Hunt, R. M. JR. \& Barnes, L. G. (1994). Basicranial evidence for ursid affinity of the oldest pinnipeds. In Contributions in Marine Mammal Paleontology Honoring Frank C. Whitmore, fr., vol. 29 (ed. A. Berta and T. A. Deméré), pp. 57-67. Proceedings of the San Diego Society of Natural History, San Diego.

*†Hunt, R. M. JR. \& Tedford, R. H. (1993). Phylogenetic relationships within the aeluroid Carnivora and implications of their temporal and geographic distribution. In Mammalian Phylogeny: Placentals (ed. F. S. Szalay, M. J. Novacek and M. G. McKenna), pp. 53-73. Springer-Verlag, New York.

* JJanczewski, D. N., Modi, W. S., Stephens, J. C. \& O’Brien, S. J. (1995). Molecular evolution of mitochondrial 12S RNA and cytochrome $\mathrm{b}$ sequences in the pantherine lineage of Felidae. Molecular Biology and Evolution 12, 690-707.

*†Janczewski, D. N., Yuhki, N., Gilbert, D. A., Jefferson, G. T. \& O'Brien, S. J. (1992). Molecular phylogenetic inference from saber-toothed cat fossils of Rancho La Brea. Proceedings of the National Academy of Sciences of the United States of America 89, 9769-9773.

$\dagger$ Jinchu, H. (1990). The history and evolution of the giant panda. In The Secret World of Pandas (ed. B. Preiss and G. Xueyu), pp. 8-13. Harry N. Abrams, New York.

Källersjö, M., Farris, J. S., Kluge, A. G. \& Bult, C. (1992). Skewness and permutation. Cladistics 8, 275-287.
*†Kim, K. C., Repenning, C. A. \& Morejohn, G. V. (1975). Specific antiquity of the sucking lice and evolution of otariid seals. Rapports et Procés-verbaux des Réunions Conseil International pour l'Exploration de la Mer 169, 544-549.

$\dagger$ Kitchener, A. (1991). The Natural History of the Wild Cats. Christopher Helm, London.

*Kleiman, D. G. (1967). Some aspects of social behavior in the Canidae. American Zoologist 7, 365-372.

Kluge, A. G. (1983). Cladistics and the classification of the great apes. In New Interpretations of Ape and Human Ancestry (ed. R. L. Ciochon and R. S. Corruccini), pp. 151-177. Plenum Press, New York.

KLUGe, A. G. (1989). A concern for evidence and a phylogenetic hypothesis of relationships among Epicrates (Boidae, Serpentes). Systematic Zoology 38, 7-25.

Kluge, A. G. \& Wolf, A. J. (1993). Cladistics: what's in a word? Cladistics 9, 183-199.

*Král, B. \& Zima, J. (1980). Karyosystematika celedi Felidae. Gazella 2/3, 45-53.

* Kratochvíl, J. (1976). Os penis der Gattung Panthera und das System der Felidae (Mammalia). Zoologické Listy 25, 289-302.

*Kratochvíl, J. (1982). Karyotyp und System der Familie Felidae (Carnivora, Mammalia). Folio Zoologica 31, 289-304.

*Langguth, A. (1969). Die südamerikanischen Canidae unter besonderer Berückischigung des Mähnenwolfes Chrysocyon brachyurus Illiger (Morphologische, systematische, und phylogenetische Untersuchungen). Zeitschrift für Wissenschaftliche Zoologie 179, 1-188.

*Langguth, A. (1975). Ecology and evolution in the South American canids. In The Wild Canids: their Systematics, Behavioral Ecology and Evolution (ed. M. W. Fox), pp. 192-206. Van Nostrand Reinhold Company, New York.

Lanyon, S. M. (1993). Phylogenetic frameworks: towards a firmer foundation for the comparative approach. Biological Journal of the Linnean Society 49, 45-61.

Lawrence, B. \& Bossert, W. H. (1967). Multiple character analysis of Canis lupus, latrans, and familiaris, with a discussion of the relationships of Canis niger. American Zoologist 7, 223-232.

Ledje, C. \& Arnason, U. (1996). Phylogenetic analyses of complete cytochrome $b$ genes of the order Carnivora with particular emphasis on the Caniformia. Fournal of Molecular Evolution 42, 135-144.

Lee, P. G., Majluf, P. \& Gordon, I. J. (1991). Growth, weaning and maternal investment from a comparative perspective. Fournal of Zoology 225, 99-114.

$\dagger$ Lehman, N., Eisenhawer, A., Hansen, K., Megh, L. D., Peterson, R. O., Gogan, P. J. P. \& Wayne, R. K. (1991). Introgression of coyote mitochondrial DNA into sympatric North American gray wolf populations. Evolution 45, 104-119.

*Lento, G. M., Hickson, R. E., Ghambers, G. K. \& Penny, D. (1995). Use of spectral analysis to test hypotheses on the origin of pinnipeds. Molecular Biology and Evolution 12, $28-52$.

*Leone, C. A. \& Wiens, A. L. (1956). Comparative serology of carnivores. Fournal of Mammalogy 37, 11-23.

* Ling, J. K. (1978). Pelage characteristics and systematic relationships in the Pinnipedia. Mammalia 42, 305-313.

*Long, C. A. (1981). Provisional classification and evolution of the badgers. Proceedings of the Worldwide Furbearer Conference $\mathbf{1}$, $55-85$.

Lotze, J.-H. \& Anderson, S. (1979). Procyon lotor. Mammalian Species 119, 1-8.

*Lushnikova, T. P., Omelyanchuk, L. V., Graphodatsky, A. S., Radjabli, S. I., Ternovskaya, Y. G. \& Ternovsky, 
D. V. (1989). Phylogenetic relationships of closely related species (Mustelidae). Interspecific variability of blothybridization patterns of BamHI repeats. Genetika 25, 1089 1094.

Maddison, W. P. \& Maddison, D. R. (1992). MacClade: Analysis of Phylogeny and Character Evolution. Version 3.0. Sinauer Associates, Sunderland, Massachusetts.

Marshall, C. R. (1990). Confidence intervals on stratigraphic ranges. Paleobiology 16, 1-10.

* $\uparrow$ Martin, L. D. (1980). Functional morphology and the evolution of cats. Transactions of the Nebraska Academy of Sciences 8, 141-154.

Martin, L. D. (1989). Fossil history of the terrestrial Carnivora. In Carnivore Behavior, Ecology, and Evolution (ed. J. L. Gittleman), pp. 536-568. Cornell University Press, Ithaca, New York.

*†Masuda, R. \& Yoshida, M. C. (1994a). A molecular phylogeny of the family Mustelidae (Mammalia, Carnivora), based on comparison of mitochondrial cytochrome b nucleotide sequences. Zoological Science 11, 605-612.

$\dagger$ Masuda, R. \& Yoshida, M. C. (1994b). Nucleotide sequence variation of cytochrome $\mathrm{b}$ genes in three species of weasels Mustela itatsi, Mustela sibirica, and Mustela nivalis, detected by improved PCR product-direct sequencing technique. Fournal of the Mammalogical Society of Japan 19, 33-43.

* Masuda, R., Yoshida, M. C., Shinyashiki, F. \& Bando, G. (1994). Molecular phylogenetic status of the Iriomote cat Felis iriomotensis, inferred from mitochondrial DNA sequence analysis. Zoological Science 11, 597-604.

MAYr, E. (1986). Uncertainty in science: is the giant panda a bear or a raccoon? Nature 323, 769-771.

* Mazza, P. \& Rustioni, M. (1994). On the phylogeny of Eurasian bears. Palaeontographica Abteilung A Palaeozoologie Stratigraphie 230, 1-38.

*MaKenna, M. C. (1991). The alpha crystallin A chain of the eye lens and mammalian phylogeny. Annales Zoologici Fennici 28, 349-360.

MaKenna, M. G. \& Bell, S. K. (1997). Classification of Mammals Above the Species Level. Columbia University Press, New York.

MaLaren, I. A. (1975). A speculative overview of phocid evolution. Rapports et Procés-verbaux des Réunions Conseil International pour l'Exploration de la Mer 169, 43-48.

MaNAB, B. K. (1995). Energy expenditure and conservation in frugivorous and mixed-diet carnivorans. Fournals of Mammalogy 76, 206-222.

Mickevich, M. F. (1978). Taxonomic congruence. Systematic Zoology 27, 143-158.

Mishler, B. D. (1994). Cladistic analysis of molecular and morphological data. American Fournal of Physical Anthropology 94, 143-156.

Miудmoto, M. M. (1985). Consensus cladograms and general classifications. Cladistics 1, 186-189.

*Modi, W. S. \& O’Brien, S. J. (1988). Quantitative cladistic analysis of chromosome banding among species in three orders of mammals: hominoid primates, felids and arvicolid rodents. In Chromosome Structure and Function: Impact of New Concepts (ed. J. P. Gustafson and R. Appels), pp. 215-242. Plenum Press, New York.

Mooers, A. Ø. \& Heard, S. J. (1997). Evolutionary process from phylogenetic tree shape. Quarterly Review of Biology 72, $31-54$.
*Morejohn, G. V. (1975). A phylogeny of otariid seals based on morphology of the baculum. Rapports et Procés-verbaux des Réunions Conseil International pour l'Exploration de la Mer 169, 49-56.

*Mouchaty, S., Cook, J. A. \& Shields, G. F. (1995). Phylogenetic analysis of northern hair seals based on nucleotide sequences of the mitochondrial cytochrome $b$ gene. Fournal of Mammalogy 76, 1178-1185.

*Nash, W. G. \& O'Brien, S. J. (1987). A comparative chromosome banding analysis of the Ursidae and their relationship to other carnivores. Cytogenetics and Cell Genetics $\mathbf{4 5}$, 206-212.

Nee, S., Holmes, E. C., Rambaut, A. \& Harvey, P. H. (1995). Inferring population history from molecular phylogenies. Philosophical Transactions of the Royal Society of London B 344, 25-31.

Nixon, K. C. \& Carpenter, J. M. (1996). On simultaneous analysis. Cladistics 12, 221-241.

* Nojima, T. (1990). A morphological consideration of the relationships of Pinnipedia to other carnivorans based on the bony tentorium and bony falx. Marine Mammal Science 6, 54-74.

Novacek, M. J. (1991). 'All tree histograms' and the evaluation of cladistic evidence: some ambiguities. Cladistics 7, 345-349.

NovaceK, M. J. (1992a). Fossils as critical data for phylogeny. In Extinction and Phylogeny (ed. M. J. Novacek and Q. D. Wheeler), pp. 46-88. Columbia University Press, New York.

Novacek, M. J. (1992b). Mammalian phylogeny: shaking the tree. Nature 356, 121-125.

*Nowak, R. M. (1978). Evolution and taxonomy of coyotes and related Canis. In Coyotes: Biology, Behavior, and Management (ed. M. Bekoff), pp. 3-16. Academic Press, New York.

* $\uparrow$ Nowak, R. M. (1979). North American Quaternary Canis. Monograph of the Museum of Natural History, University of Kansas 6, 1-154.

Nowak, R. M. (1991). Walker's Mammals of the World. Fifth edition. The Johns Hopkins University Press, Baltimore.

*†O'Brien, S. J., Collier, G. E., Benveniste, R. E., Nash, W. G., Newman, A. K., Simonson, J. M., Eichelberger, M. A., Seal, U. S., Janssen, D., Bush, M. \& Wildt, D. E. (1987). Setting the molecular clock in Felidae: the great cats, Panthera. In Tigers of the World: Biology, Biopolitics, Management and Conservation of an Endangered Species (ed. R. L. Tilson and U. S. Seal), pp. 10-27. Noyes Publications, Parkridge, New Jersey.

*†O'Brien, S. J., Martenson, J. S., Eichelberger, M. A., Thorne, E. T. \& Wright, F. (1989). Genetic variation and molecular systematics of the black-footed ferret. In Conservation Biology and the Black-Footed Ferret (ed. U. S. Seal, E. T. Thorne, M. A. Bogan and S. H. Anderson), pp. 21-33. Yale University Press, New Haven, Connecticut.

O'Brien, S.J., Martenson, J. S., Miththapala, S., Janczewski, D., Pecon-Slattery, J., Johnson, W., Gilbert, D. A., Roelke, M., Pagker, G., Bush, M. \& Wildt, D. E. (1996). Conservation genetics of the Felidae. In Case Histories from Nature (ed. J. C. Avise and J. L. Hamrick), pp. 50-74. Chapman and Hall, New York.

*†O'Brien, S. J., Nash, W. G., Wildt, D. E., Bush, M. E. \& Benveniste, R. E. (1985). A molecular solution to the riddle of the giant panda's phylogeny. Nature 317, 140-144.

*Obara, Y. (1991). Karyosystematics of the mustelid carnivores of Japan. Honyurui Kagaku 30, 197-220. 
Olson, S. L. \& Pregill, G. K. (1982). Introduction to the paleontology of Bahaman vertebrates. In Fossil Vertebrates from the Bahamas, vol. 48 (ed. S. L. Olson), pp. 1-7. Smithsonian Contributions to Paleobiology, Washington.

Ortolani, A. \& Caro, T. M. (1996). The adaptive significance of color patterns in carnivores: phylogenetic tests of classic hypotheses. In Carnivore Behavior, Ecology, and Evolution, vol. 2 (ed. J. L. Gittleman), pp. 132-188. Cornell University Press, Ithaca, New York.

* † Pecon Slattery, J., Johnson, W. E., Goldman, D. \& O'Brien, S. J. (1994). Phylogenetic reconstruction of South American felids defined by protein electrophoresis. Fournal of Molecular Evolution 39, 296-305.

*†Pecon Slattery, J. \& O'Brien, S. J. (1995). Molecular phylogeny of the red panda (Ailurus fulgens). Fournal of Heredity 86, 413-422.

Penny, D. \& Hendy, M. D. (1986). Estimating the reliability of evolutionary trees. Molecular Biology and Evolution 3, 403-417.

*†Perry, E. A., Carr, S. M., Bartlett, S. E. \& Davidson, W. S. (1995). A phylogenetic perspective on the evolution of reproductive behavior in pagophilic seals of the northwest Atlantic as indicated by mitochondrial DNA sequences. Fournal of Mammalogy 76, 22-31.

Peters, G. (1982). A note on the vocal behaviour of the giant panda, Ailuropoda melanoleuca (David, 1869). Zeitschrift für Säugetierkunde 47, 236-246.

*Peters, G. (1987). Acoustic communication in the genus Lynx (Mammalia: Felidae) - comparative survey and phylogenetic interpretation. Bonner zoologische Beiträge 38, 315-330.

* Petter, G. (1971). Origine, phylogenie et systématique des blaireaux. Mammalia 35, 567-597.

* Petter, G. (1974). Rapports phylétiques des Viverridés (Carnivores Fissipèdes). Les formes de Madagascar. Mammalia 38, 605-636.

*Phillips, M. K. \& Henry, V. G. (1992). Comments on red wolf taxonomy. Conservation Biology 6, 596-599.

Poglayen-Neuwall, I. \& Poglayen-Neuwall, I. (1965). Gefangenschaftsbeobachtungen an Makibären (Bassaricyon Allen, 1876). Zeitschrift für Säugetierkunde 30, 321-366.

Purvis, A. (1995 a). A composite estimate of primate phylogeny. Philosophical Transactions of the Royal Society of London B 348, 405-421.

Purvis, A. $(1995 b)$. A modification to Baum and Ragan's method for combining phylogenetic trees. Systematic Biology 44, 251-255.

Purvis, A. (1996). Using interspecies phylogenies to test macroevolutionary hypotheses. In New Uses for New Phylogenies (ed. P. H. Harvey, A. J. Leigh Brown, J. Maynard Smith and S. Nee), pp. 153-168. Oxford University Press, Oxford.

Purvis, A., Gittleman, J. L. \& Luh, H.-K. (1994). Truth or consequences: effects of phylogenetic accuracy on two comparative methods. Fournal of Theoretical Biology 167, 293-300.

Purvis, A., Nee, S. \& Harvey, P. H. (1995). Macroevolutionary inferences from primate phylogeny. Proceedings of the Royal Society of London B 260, 329-333.

*Qui, Z.-X. (1987). Die Hyaeniden aus dem Ruscinium und Villafranchium Chinas. Münchner Geowissenschaftliche Abhandlungen Reihe A Geologie und Palänotologie 9, 1-110.

$* \dagger$ Radinsky, L. (1975). Viverrid neuroanatomy: phylogenetic and behavioral implications. Fournal of Mammalogy 56, $130-150$. $\nmid$ Radinsky, L. B. (1982). Evolution of skull shape in carnivores. 3 . The origin and early radiation of the modern carnivore families. Paleobiology 8, 177-195.

Ragan, M. A. (1992). Phylogenetic inference based on matrix representation of trees. Molecular Phylogenetics and Evolution 1, $53-58$.

Rambaut, A., Harvey, P. H. \& Nee, S. (1997). End-Epi: an application for inferring phylogenetic and population dynamical processes from molecular sequences. Computer Applications in the Biosciences 13, 303-306.

$\dagger$ Randi, E. \& RAGni, B. (1991). Genetic variability and biochemical systematics of domestic and wild cat populations (Felis silvestris: Felidae). Journal of Mammalogy 72, 79-88.

RAY, C. E. (1976). Geography of phocid evolution. Systematic Zoology 25, 391-406.

$\dagger$ Repenning, G. A., Ray, C. E. \& Grigorescu, D. (1979). Pinniped biogeography. In Historical Biogeography, Plate Tectonics, and the Changing Environment (ed. J. Gray and A. J. Boucot). Oregon State University Press, Corvallis, Oregon.

Repenning, G. A. \& Tedford, R. H. (1977). Otarioid seals of the Neogene: classification, historical zoogeography, and temporal correlation of the sea lions and walruses from the North Pacific region. U.S. Geological Survey Professional Paper 992, 1-93.

*Robinson, R. (1979). Cytogenetics of the Felidae. Carnivore 2, 63-68.

*Rodewald, K., Braunitzer, G. \& Göltenboth, R. (1988). Carnivora: primary structure of the hemoglobins from Ratel (Mellivora capensis). Biological Chemistry Hoppe-Seyler 369, $1137-$ 1142.

Rodrigo, A. G., Kelly-Borges, M., Bergquist, P. R. \& Bergquist, P. L. (1993). A randomisation test of the null hypothesis that two cladograms are sample estimates of a parametric phylogenetic tree. New Zealand Fournal of Botany 31, 257-268.

Ronquist, F. (1996). Matrix representation of trees, redundancy, and weighting. Systematic Biology 45, 247-253.

*Roy, M. S., Geffen, E., Smith, D., Ostrander, E. A. \& Wayne, R. K. (1994). Patterns of differentiation and hybridization in North American wolflike canids, revealed by analysis of microsatellite data. Molecular Biology and Evolution 11, 553-570.

*Russell, A. P., Bryant, H. N., Powell, G. L. \& Laroiya, R. (1995). Scaling relationships within the maxillary tooth row of the Felidae, and the absence of the second upper premolar in Lynx. Fournal of Zoology 236, 161-182.

*Salles, L. O. (1992). Felid phylogenetics: extant taxa and skull morphology (Felidae, Aeluroidae). American Museum Novitates 3047, 1-67.

Sanderson, M.J., Donoghue, M. J., Piel, W. \& Eriksson, T. (1994). TreeBASE: a prototype database of phylogenetic analyses and an interactive tool for browsing the phylogeny of life. American Fournal of Botany 81, 183.

Sanderson, M. J., Purvis, A. \& Henze, C. (1998). Phylogenetic supertrees: assembling the trees of life. Trends in Ecology and Evolution 13, 105-109.

* † SArich, V. M. (1969a). Pinniped origins and the rate of evolution of carnivore albumins. Systematic Zoology 18, 286295.

$* \uparrow$ SARICh, V. M. $(1969 b)$. Pinniped phylogeny. Systematic Zoology 18, 416-422.

SARICH, V. M. (1975). Pinniped systematics: immunological 
comparisons of their albumins and transferrins. American Zoologist 15, 826.

* † SARICH, V. M. (1976). Transferrin. Transactions of the Zoological Society of London 33, 165-171.

$\uparrow$ Savage, D. E. \& Russell, D. E. (1983). Mammalian Paleofaunas of the World. Addison-Wesley, London.

*Schmidt-Kittler, V. (1981). Zur Stammesgeschichte der marderverwandten Raubtiergruppen (Musteloidea, Carnivora). Eclogae Geologicae Helvetiae 74, 753-801.

*Schreiber, A., Puschmann, W. \& Tighy, H. (1993). On the taxonomy of Amur cat (Felis bengalensis euptilura). Zeitschrift für Säugetierkunde 58, 13-17.

*†Seal, U. S., Phillips, N. I. \& Erickson, A. W. (1970). Carnivora systematics: immunological relationships of bear serum albumin. Comparative Biochemistry and Physiology 32, 33-48.

* + Shields, G. F. \& Kocher, T. D. (1991). Phylogenetic relationships of North American ursids based on analysis of mitochondrial DNA. Evolution 45, 218-221.

$*+$ Simonsen, V. (1982). Electrophoretic variation in large mammals. II. The red fox, Vulpes vulpes, the stoat, Mustela erminea, the weasel, Mustela nivalis, the pole cat, Mustela putorius, the pine marten, Martes martes, the beech marten, Martes foina, and the badger, Meles meles. Hereditas 96, 299-305.

Simpson, G. G. (1945). The principles of classification and a classification of mammals. Bulletin of the American Museum of Natural History 85, 1-350.

* $†$ Slade, R. W., Moritz, C. \& Heideman, A. (1994). Multiple nuclear-gene phylogenies: application to pinnipeds and comparison with a mitochondrial DNA gene phylogeny. Molecular Biology and Evolution 11, 341-356.

Sokolov, V. E., Rozhnov, V. V. \& Anh, P. T. (1997). New species of viverrids of the genus Viverra (Mammalia, Carnivora) from Vietnam. Zoologischeskii Zhurnal 76, 585-589.

*Stains, H. (1976). Calcanea of members of the Mustelidae. Part I. Mustelinae. Bulletin of the Southern California Academy of Science 75, 237-248.

*Stains, H.J. (1975). Distribution and taxonomy of the Canidae. In The Wild Canids: their Systematics, Behavioral Ecology and Evolution (ed. M. W. Fox), pp. 3-26. Van Nostrand Reinhold Company, New York.

*Stains, H. J. (1983). Calcanea of members of the Viverridae. Bulletin of the Southern California Academy of Sciences 82, 17-38.

Stehli, F. G. \& Webi, S. D. (1985). The Great American Biotic Interchange. Plenum Press, New York.

*Stirling, I. \& Warneke, R. M. (1971). Implications of a comparison of the airborne vocalizations and some aspects of the behaviour of the two Australian fur seals, Arctocephalus spp., on the evolution and present taxonomy of the genus. Australian Fournal of Zoology 19, 227-241.

Swofford, D. L. (1991). When are phylogeny estimates from molecular and morphological data incongruent? In Phylogenetic Analysis of DNA Sequences (ed. M. M. Miyamoto and J. Cracraft), pp. 295-333. Oxford University Press, Oxford.

Swofford, D. L. (1993). PAUP: Phylogenetic Analysis Using Parsimony, Version 3.1.1. Computer program distributed by the Illinois Natural History Survey, Champaign, Illinois.

*Taberlet, P. \& Bouvet, J. (1992). Génétique de l'Ours brun des Pyrénées (Ursus arctos): premiers résultats. Comptes Rendus de l'Académie des Sciences Série III Sciences de la Vie 314, 15-21.

*Tagle, D. A., Miyamoto, M. M., Goodman, M., Hofmann, O., Braunitzer, G., Göltenboth, R. \& Jalanka, H. (1986).
Hemoglobin of pandas: phylogenetic relationships of carnivores as ascertained with protein sequence data. Naturwissenschaften 73, 512-514.

Talbot, S. L. \& Shields, G. F. (1996). Phylogeography of brown bears (Ursus arctos) of Alaska and paraphyly within the Ursidae. Molecular Phylogenetics and Evolution 5, 477-494.

*TAYlor, M. E. (1988). Foot structure and phylogeny in the Viverridae (Carnivora). Journal of Zoology 216, 131-139.

*†Taylor, P. J., Campbell, G. K., Meester, J. A. J. \& Van DYк, D. (1991). A study of allozyme evolution in African mongooses (Viverridae: Herpestinae). Zeitschrift für Säugetierkunde 56, 135-145.

*Tedford, R. H. (1976). Relationships of pinnipeds to other carnivores (Mammalia). Systematic Zoology 25, 363-374.

*Tedford, R. H., Taylor, B. E. \& Wang, X. (1995). Phylogeny of the Caninae (Carnivora: Canidae): the living taxa. American Museum Novitates 3146, 1-37.

*†Thenius, E. (1976). Zur stammegeschichtlichen herkunft von Tremarctos (Ursidae, Mammalia). Zeitschrift für Säugetierkunde 41, 109-114.

* † Thenius, E. (1979). Zur systematischen und phylogenetischen Stellung des Bambusbären: Ailuropoda melanoleuca David (Carnivora, Mammalia). Zeitschrift für Säugetierkunde 44, 286-305.

*Todd, N. B. (1970). Karyotypic fissioning and canid phylogeny. Fournal of Theoretical Biology 26, 445-480.

*Trajano, E. \& Ferrarezzi, H. (1994). A fossil bear from northeastern Brazil, with a phylogenetic analysis of the South American extinct Tremarctinae (Ursidae). Fournal of Vertebrate Paleontology 14, 552-561.

*Trillmich, F. \& Majluf, P. (1981). First observations on colony structure, behavior, and vocal repertoire of the South American fur seal (Arctocephalus australis Zimmermann, 1783) in Peru. Zeitschrift für Säugetierkunde 46, 310-322.

*Tumlison, R. \& MaDaniel, V. R. (1984). A description of the baculum of the bobcat (Felis rufus), with comments on its development and taxonomic implications. Canadian Fournal of Zoology 62, 1172-1176.

*Van Gelder, R. G. (1978). A review of canid classification. American Museum Novitates 2646, 1-10.

*Van Zyll de Jong, C. G. (1987). A phylogenetic study of the Lutrinae (Carnivora; Mustelidae) using morphological data. Canadian Fournal of Zoology 65, 2536-2544.

Vázquez, D. P. \& Gittleman, J. L. (1998). Biodiversity conservation: does phylogeny matter? Current Biology 8, R379-R381.

*†Veron, G. \& Catzeflis, F. M. (1993). Phylogenetic relationships of the endemic Malagasy carnivore Cryptoprocta ferox (Aeluroideae): DNA/DNA hybridization experiments. Fournal of Mammalian Evolution 1, 169-185.

*Vrana, P. B., Milinkovitah, M. C., Powell, J. R. \& Wheeler, W. G. (1994). Higher level relationships of the arctoid Carnivora based on sequence data and 'total evidence'. Molecular Phylogenetics and Evolution 3, 47-58.

Wang, X. (1994). Phylogenetic systematics of the Hesperocyoninae (Carnivora: Canidae). Bulletin of the American Museum of Natural History 221, 1-207.

* +Wayne, R. K., Benveniste, R. E., Janczewski, D. N. \& O'Brien, S. J. (1989a). Molecular and biochemical evolution of the Carnivora. In Carnivore Behavior, Ecology, and Evolution (ed. J. L. Gittleman), pp. 465-494. Cornell University Press, Ithaca, New York. 
*Wayne, R. K. \& Jenks, S. M. (1991). Mitochondrial DNA analysis implying extensive hybridization of the endangered red wolf Canis rufus. Nature 351, 565-568.

*Wayne, R. K., Meyer, A., Lehman, N., Van Valkenburgh, B., Kat, P. W., Fuller, T. K., Girman, D. J. \& O'Brien, S. J. (1990). Large sequence divergence among mitochondrial DNA genotypes within populations of eastern African blackbacked jackals. Proceedings of the National Academy of Sciences of the United States of America 87, 1772-1776.

*†Wayne, R. K., Nash, W. G. \& O'Brien, S. J. (1987a). Chromosomal evolution of the Canidae: I. Species with high diploid numbers. Cytogenetics and Cell Genetics 44, 123-133.

* Whayne, R. K., Nash, W. G. \& O’Brien, S. J. (1987 b). Chromosomal evolution of the Canidae: II. Divergence from the primitive carnivoran karyotype. Cytogenetics and Cell Genetics 44, 134-141.

* Whayne, R. K. \& O’Brien, S. J. (1987). Allozyme divergence within the Canidae. Systematic Zoology 36, 339-355.

†Wayne, R. K., Van Valkenburgh, B., Kat, P. W., Fuller, T. K., Johnson, W. E. \& O'Brien, S. J. (1989b). Genetic and morphological divergence among sympatric canids. Fournal of Heredity 80, 447-454.

†Wayne, R. K., Van Valkenburgh, B. \& O'Brien, S. J. (1991). Molecular distance and divergence time in carnivores and primates. Molecular Biology and Evolution 8, 297-319.

*†Werdelin, L. (1981). The evolution of lynxes. Annales Zoologici Fennici 18, 37-71.

*Werdelin, L. (1983). Morphological patterns in the skulls of cats. Biological Fournal of the Linnean Society 19, 375-391.

*Werdelin, L. (1996). Carnivoran ecomorphology: a phylogenetic perspective. In Carnivore Behavior, Ecology, and Evolution, vol. 2 (ed. J. L. Gittleman), pp. 582-624. Cornell University Press, Ithaca, New York.

*†Werdelin, L. \& Solounias, N. (1991). The Hyaenidae: taxonomy, systematics and evolution. Fossils and Strata 30, $1-104$.

Wheeler, W. C. (1992). Extinction, sampling, and molecular phylogenetics. In Extinction and Phylogeny (ed. M. J. Novacek and Q. D. Wheeler), pp. 205-215. Columbia University Press, New York.

White, B. N. (1986). The isthmian link, antitropicality and American biogeography: distributional history of the Atherinopsinae (Pisces: Atherinidae). Systematic Zoology 35, 176-194.

WIIG, Ø. (1985). Relationship of Nandinia binotata (Gray) to the superfamily Feloidea (Mammalia, Carnivora). Zoologica Scripta 14, 155-159.

Wilkinson, M. (1995). Coping with abundant missing entries in phylogenetic inference using parsimony. Systematic Biology 44, 501-514.

*Wolsan, M. (1993). Phylogeny and classification of early European Mustelida (Mammalia: Carnivora). Acta Theriologica 38, 345-384.

Woodroffe, R. \& Ginsberg, J. R. (1998). Edge effects and the extinction of populations inside protected areas. Science $\mathbf{2 8 0}$, 2126-2128.

*Wozencraft, W. C. (1984). A phylogenetic reappraisal of the Viverridae and its relationship to other Carnivora. Ph.D. thesis, University of Kansas, Lawrence.

*Wozencraft, W. G. (1989). The phylogeny of the Recent Carnivora. In Carnivore Behavior, Ecology, and Evolution (ed. J. L. Gittleman), pp. 495-535. Cornell University Press, Ithaca, New York.
*Wozencraft, W. C. (1993). Order Carnivora. In Mammal Species of the World: a Taxonomic and Geographic Reference (ed. D. E. Wilson and D. A. Reeder), pp. 279-348. Smithsonian Institution Press, Washington.

*Wurster, D. H. (1969). Cytogenetic and phylogenetic studies in Carnivora. In Comparative Mammalian Cytogenetics (ed. K. Benirschke), pp. 310-329. Springer-Verlag, New York.

*Wurster-Hill, D. H. \& Centerwall, W. R. (1982). The interrelationships of chromosome banding patterns in canids, mustelids, hyena, and felids. Cytogenetics and Cell Genetics 34, 178-192.

*Wyss, A. R. (1987). The walrus auditory region and the monophyly of pinnipeds. American Museum Novitates 2871, $1-31$.

*Wyss, A. R. (1988). On 'retrogression' in the evolution of the Phocinae and phylogenetic affinities of the monk seals. American Museum Novitates 2924, 1-38.

*Wyss, A. R. \& Flynn, J.J. (1993). A phylogenetic analysis and definition of the Carnivora. In Mammalian Phylogeny: Placentals (ed. F. S. Szalay, M. J. Novacek and M. G. McKenna), pp. 32-52. Springer-Verlag, New York.

*Youngman, P. M. (1982). Distribution and systematics of the European mink Mustela lutreola Linnaeus 1761. Acta Zoologica Fennica 166, 1-48.

* $†$ Zhang, Y.-P. \& Ryder, O. A. (1993). Mitochondrial DNA sequence evolution in the Arctoidea. Proceedings of the National Academy of Sciences of the United States of America 90, 9557-9561.

* $†$ Zhang, Y.-P. \& Ryder, O. A. (1994). Phylogenetic relationships of bears (the Ursidae) inferred from mitochondrial DNA sequences. Molecular Phylogenetics and Evolution 3, 351-359.

*Zhang, Y.-P. \& ShI, L.-M. (1991). Riddle of the giant panda. Nature 352, 573.

\section{APPENDIX}

The following references were used as source trees and/or to provide date estimates for the composite phylogeny. References are divided according to the various matrices they contributed to and so may appear more than once. The matrices and composite trees have been deposited on TreeBASE (see Sanderson et al., 1994; study accession number 5355; matrix accession numbers M472-484; http://www.herbaria.harvard.edu/treebase/) and are also available from O.R.P.B.-E. on request.

Higher groups (excluding Hyaenidae) (Fig. 1, Table 2)

Source trees: Gregory \& Hellman, 1939; Leone \& Wiens, 1956; Wurster, 1969; Hunt, 1974; Sarich, 1975; Tedford, 1976; Arnason, 1977; Bugge, 1978; Hendey, 1978; Ling, 1978; Schmidt-Kittler, 1981; Dutrillaux, Couturier \& Chauvier, 1982; Flynn \& Galiano, 1982; Ginsburg, 1982; Wozencraft, 1984, 1989; Couturier \& Dutrillaux, 1985; de Jong, 1986; Braunitzer \& Hofmann, 1987; Wyss, 1987; Flynn et al., 1988; Holmes, 1988; Rodewald, Braunitzer \& Göltenboth, 1988; Ahmed, Jahan \& Braunitzer, 1990; Czelusniak et al., 1990, 1991; Nojima, 1990; McKenna, 1991; 
Arnason \& Ledje, 1993; Wolsan, 1993; Wyss \& Flynn, 1993; Berta \& Wyss, 1994; Hunt \& Barnes, 1994; Vrana et al., 1994; Lento et al., 1995; Austin, 1996; Bininda-Emonds \& Russell, 1996; Werdelin, 1996

Date estimates: Repenning, Ray \& Grigorescu, 1979; Martin, 1980; Radinsky, 1982; Savage \& Russell, 1983; Barnes, Domning \& Ray, 1985; Gittleman, 1986; Anderson, 1989; Jinchu, 1990; Wayne et al., 1991; Werdelin \& Solounias, 1991; Janczewski et al., 1995; Hunt, 1996

Both: Sarich, $1969 a, b, 1976$; Seal et al., 1970; Radinsky, 1975; Thenius, 1979; Goodman et al., 1982; O'Brien et al., 1985; Goldman et al., 1989; Wayne et al., 1989 a; Janczewski et al., 1992; Garland et al., 1993; Hashimoto et al., 1993; Hunt \& Tedford, 1993; Veron \& Catzeflis, 1993; Masuda \& Yoshida, $1994 a$; Slade, Moritz \& Heideman, 1994; Arnason et al., 1995; Pecon Slattery \& O’Brien, 1995

Mustelidae (excluding Lutrinae and Mephitinae) (Fig. 2, Table 3)

Source trees: Petter, 1971; Graphodatsky et al., 1976, 1989; Stains, 1976; Long, 1981; Schmidt-Kittler, 1981; de Muizon, $1982 a$; Youngman, 1982; Belyaev et al., 1984; Wozencraft, 1984, 1989, 1993; Couturier \& Dutrillaux, 1985; Arnason \& Widegren, 1986; Holmes, 1988; Lushnikova et al., 1989; Obara, 1991; Vrana et al., 1994

Date estimates: Sarich, 1976; Savage \& Russell, 1983; Anderson et al., 1986; Wayne et al., 1991; Garland et al., 1993; Masuda \& Yoshida, 1994b; Hunt, 1996

Both: Anderson, 1970, 1989; Simonsen, 1982; Hartl et al., 1988; O’Brien et al., 1989; Wayne et al., 1989 a; Bryant, Russell \& Fitch, 1993; Hashimoto et al., 1993; Hosoda et al., 1993; Masuda \& Yoshida, $1994 a$

Lutrinae (Fig. 3, Table 4)

Source trees: Davis, 1978; de Muizon, $1982 a$; van Zyll de Jong, 1987; Holmes, 1988; Bryant et al., 1993; Wozencraft, 1993

Date estimates: Savage \& Russell, 1983; Wayne et al., 1991 ; Masuda \& Yoshida, $1994 a$

\section{Mephitinae (Fig. 4, Table 5)}

Source trees: Holmes, 1988; Bryant et al., 1993; Wozencraft, 1993

Date estimates: Savage \& Russell, 1983; O'Brien et al., 1989; Wayne et al., 1989 a, 1991

Both: Dragoo et al., 1993

\section{Procyonidae (Fig. 5, Table 6)}

Source trees: Couturier \& Dutrillaux, 1985; Decker \& Wozencraft, 1991; Wozencraft, 1993

Date estimates: Sarich, 1976; Savage \& Russell, 1983;
Wayne et al., $1989 a$; Garland et al., 1993; Hunt, 1996 Both: Baskin, 1982; Zhang \& Ryder, 1993; Pecon Slattery \& O'Brien, 1995

Otariidae (Fig. 6, Table 7)

Source trees: Sarich, 1969b, 1975; Stirling \& Warneke, 1971; Morejohn, 1975; Ling, 1978; Trillmich \& Majluf, 1981; Berta \& Deméré, 1986; Beentjes, 1990; Wozencraft, 1993; Berta \& Wyss, 1994; Hirota, 1994; Lento et al., 1995

Date estimates: Repenning et al., 1979; Bogdanov \& Pastukhov, 1982; Savage \& Russell, 1983; Hoberg \& Adams, 1992

Both: Kim, Repenning \& Morejohn, 1975; Sarich, 1976; Barnes et al., 1985; Arnason et al., 1995

Phocidae (Fig. 7, Table 8)

Source trees: Chapskii, 1955; Burns \& Fay, 1970; Anbinder, 1971; Sarich, 1975; Ling, 1978; de Muizon, $1982 b$; Couturier \& Dutrillaux, 1985; Wyss, 1988; Nojima, 1990; Wozencraft, 1993; Berta \& Wyss, 1994; Lento et al., 1995; Mouchaty et al., 1995; Bininda-Emonds \& Russell, 1996

Date estimates: Repenning et al., 1979; Savage \& Russell, 1983; Hoberg \& Adams, 1992; Arnason et al., 1993

Both: Sarich, 1969b, 1976; Hendey, 1972; Bogdanov \& Pastukhov, 1982; Slade et al., 1994; Arnason et al., 1995; Perry et al., 1995

\section{Ursidae (Fig. 8, Table 9)}

Source trees: Wurster, 1969; Seal et al., 1970; Nash \& O’Brien, 1987; Czelusniak et al., 1990, 1991; Zhang \& Shi, 1991; Taberlet \& Bouvet, 1992; Wozencraft, 1993; Mazza \& Rustioni, 1994; Trajano \& Ferrarezzi, 1994; Vrana et al., 1994

Date estimates: Sarich, 1976; Savage \& Russell, 1983; Jinchu, 1990; Wayne et al., 1991; Janczewski et al., 1992, 1995; Zhang \& Ryder, 1993; Hunt, 1996

Both: Thenius, 1976, 1979; Ficcarelli, 1979; O'Brien et al., 1985; Hofmann \& Braunitzer, 1987; Goldman et al., 1989; Wayne et al., 1989 a Cronin et al., 1991; Shields \& Kocher, 1991; Garland et al., 1993; Hashimoto et al., 1993; Zhang \& Ryder, 1994; Arnason et al., 1995; Pecon Slattery \& O’Brien, 1995

\section{Canidae (Fig. 9, Table 10)}

Source trees: Kleiman, 1967; Langguth, 1969, 1975; Todd, 1970; Atkins \& Dillon, 1971; Fox, 1971; Chiarelli, 1975; Stains, 1975; Clutton-Brock, Corbet \& Hills, 1976; Darbre \& Lehmann, 1976; Atkins, 1978; Nowak, 1978; Van Gelder, 1978; Tagle et al., 1986; Braunitzer \& Hofmann, 1987; Czelusniak et al., 1990; Wayne et al., 1990; Wayne \& Jenks, 1991; Phillips \& Henry, 1992; 
Girman et al., 1993; Wozencraft, 1993; Roy et al., 1994; Vrana et al., 1994; Tedford et al., 1995

Date estimates: Savage \& Russell, 1983; Wayne et al., 1989 b, 1991; Lehman et al., 1991; Janczewski et al., 1992; Hunt, 1996

Both: Nowak, 1979; Berta, 1987; Wayne, Nash \& O'Brien, $1987 a, b$; Wayne \& O'Brien, 1987; Wayne et al., 1989 a; Geffen et al., 1992, 1996; Garland et al., 1993; Hosoda et al., 1993; Gottelli et al., 1994

Hyaenidae (Fig. 1, Table 2)

Source trees: Gregory \& Hellman, 1939; Galiano \& Frailey, 1977; Howell \& Petter, 1980; Qui, 1987; Wozencraft, 1993

Date estimates: Savage \& Russell, 1983; Wayne et al., $1989 a$, 1991; Garland et al., 1993; Veron \& Catzeflis, 1993

Both: Werdelin \& Solounias, 1991

Felidae (Fig. 10, Table 11)

Source trees: Kratochvíl, 1976, 1982; Glass \& Martin, 1978; Hemmer, 1978, 1981; Robinson, 1979; Král \& Zima, 1980; Grove, 1982; Wurster-Hill \& Centerwall, 1982; Herrington, 1983, 1986; Werdelin, 1983; Tumlison \& McDaniel, 1984; Couturier \& Dutrillaux, 1985; Tagle et al., 1986; Peters, 1987; Modi \& O’Brien, 1988; Czelusniak et al., 1990; Ahmed, Jahan \& Braunitzer, 1992; Salles, 1992; Schreiber, Puschmann
\& Tichy, 1993; Wozencraft, 1993; Masuda et al., 1994; Vrana et al., 1994; Russell et al., 1995; Decker, 1996

Date estimates: Savage \& Russell, 1983; Centerwall, Wurster-Hill \& Benveniste, 1985; Kitchener, 1991; Randi \& Ragni, 1991; Wayne et al., 1991; Arnason et al., 1995; Hunt, 1996

Both: Martin, 1980; Werdelin, 1981; Benveniste, 1985; Collier \& O'Brien, 1985; O'Brien et al., 1987; Essop, Emmanuel \& Harley, 1988; Wayne et al., $1989 a$; Janczewski et al., 1992, 1995; Garland et al., 1993; Veron \& Catzeflis, 1993; Pecon Slattery et al., 1994

Herpestidae (Fig. 11, Table 12)

Source trees: Gregory \& Hellman, 1939; Fredga, 1972; Petter, 1974; Stains, 1983; Couturier \& Dutrillaux, 1985; Taylor, 1988; Wozencraft, 1993; Austin, 1996

Date estimates: Savage \& Russell, 1983; Wayne et al., 1991; Veron \& Catzeflis, 1993

Both: Taylor et al., 1991

Viverridae (Fig. 12, Table 13)

Source trees: Gregory \& Hellman, 1939; Petter, 1974; Crawford-Cabral, 1982; Stains, 1983; Wozencraft, 1984, 1993; Couturier \& Dutrillaux, 1985; Taylor, 1988

Date estimates: Savage \& Russell, 1983; Wayne et al., 1989 a; Hunt, 1996

Both: Veron \& Catzeflis, 1993 